\title{
Extracellular annexins and dynamin are important for sequential steps in myoblast fusion
}

\author{
Evgenia Leikina, ${ }^{1}$ Kamran Melikov, ${ }^{1}$ Sarmistha Sanyal, ${ }^{1}$ Santosh K. Verma, ${ }^{1}$ Bokkee Eun, ${ }^{2}$ Claudia Gebert, ${ }^{2}$ \\ Karl Pfeifer, ${ }^{2}$ Vladimir A. Lizunov, ${ }^{3}$ Michael M. Kozlov, ${ }^{4}$ and Leonid V. Chernomordik' \\ 'Section on Membrane Biology, Program of Physical Biology; ${ }^{2}$ Section on Genome Imprinting, Program on Genomics of Differentiation; and ${ }^{3}$ Laboratory of Cellular and \\ Molecular Biophysics, Program of Physical Biology, Eunice Kennedy Shriver National Institute of Child Health and Human Development, National Institutes of Health, \\ Bethesda, MD 20892 \\ ${ }^{4}$ Department of Physiology and Pharmacology, Sackler Faculty of Medicine, Tel Aviv University, 69978 Tel Aviv, Israel
}

M yoblast fusion into multinucleated myotubes is a crucial step in skeletal muscle development and regeneration. Here, we accumulated murine myoblasts at the ready-to-fuse stage by blocking formation of early fusion intermediates with lysophosphatidylcholine. Lifting the block allowed us to explore a largely synchronized fusion. We found that initial merger of two cell membranes detected as lipid mixing involved extracellular annexins $A 1$ and $A 5$ acting in a functionally redundant manner. Subsequent stages of myoblast fusion depended on dynamin activity, phosphatidylinositol $(4,5)$ bisphosphate content, and cell metabolism. Uncoupling fusion from preceding stages of myogenesis will help in the analysis of the interplay between protein machines that initiate and complete cell unification and in the identification of additional protein players controlling different fusion stages.

\section{Introduction}

Cell-to-cell fusion is a key step in many developmental processes including fertilization and the formation of bone, placenta, and muscles (Chen et al., 2007; Sapir et al., 2008). In mature organisms, cell fusion is required for muscle repair and for the formation of multinucleated giant cells during inflammatory reactions. In each case, initial local merger of the membranes is followed by a transformation of the adhesive junction between the fusing cells into an expanding cytoplasmic bridge. A key challenge in studying the fusion stage of syncytium formation is to isolate the actual fusion event from processes that prepare the cells for fusion. For example, fusion of myoblasts-one of the very important examples of cellto-cell fusion-is preceded by myoblast differentiation, acquisition of fusion competence, and recognition and adhesion between myoblasts. Many proteins, including actin machinery, ferlins, and certain guanine nucleotide exchange factors, are required for formation of multinucleated myotubes (Doherty et al., 2005; Kim et al., 2007; Onel and RenkawitzPohl, 2009; Rochlin et al., 2010; Sens et al., 2010; Abmayr

Correspondence to Leonid V. Chernomordik: chernoml@mail.nih.gov

Abbreviations used in this paper: Anx, annexin; DM, differentiation medium; DNM, dynamin; LPC, lysophosphatidylcholine; MHC, myosin heavy chain; MiTMAB, myristyl trimethyl ammonium bromide; $\mathrm{PS}$, phosphatidylserine; $\operatorname{Ptdlns}(4,5)$ P2, phosphatidylinositol $(4,5)$ bisphosphate; $r A 1$, recombinant Anx Al; WT, wild type. and Pavlath, 2012; Gruenbaum-Cohen et al., 2012). However, these proteins are thought to mediate different pre and postfusion stages. The proteins that are involved in the cell fusion event itself remain unidentified.

The dependence of myotube formation on extracellular $\mathrm{Ca}^{2+}$ (Shainberg et al., 1969; Wakelam, 1983) and a transient exposure of phosphatidylserine (PS) in the outer leaflet of the plasma membrane of fusion-committed myoblasts (Sessions and Horwitz, 1983; van den Eijnde et al., 2001; Kaspar and Dvorák, 2008) at cell-cell contact sites (Jeong and Conboy, 2011) suggest involvement of annexins (Anxs) in myoblast fusion. Anxs are a large family of structurally related proteins whose common property is $\mathrm{Ca}^{2+}$-dependent binding to anionic phospholipids such as PS (Moss and Morgan, 2004; Gerke et al., 2005; van Genderen et al., 2008). Anxs are ubiquitous and abundant proteins and are found in both intra- and extracellular milieux. Anxs share a conserved C-terminal domain containing $\mathrm{Ca}^{2+}$ binding sites but have a variable $\mathrm{N}$-terminal domain (Gerke and Moss, 2002). It has been suggested that Anxs patch membrane microinjuries (Bouter et al., 2011), serve as membrane-membrane

This article is distributed under the terms of an Attribution-Noncommercial-Share Alike-No Mirror Sites license for the first six months after the publication date (see http://www.rupress .org/terms). After six months it is available under a Creative Commons License (AttributionNoncommercial-Share Alike 3.0 Unported license, as described at http://creativecommons .org/licenses/by-nc-sa/3.0/). 
linkers, bend and fuse membranes (Gerke and Moss, 2002; van Genderen et al., 2008), and anchor other proteins to the membranes (Gerke and Moss, 2002). Different Anxs have been implicated in many intra- and extracellular processes, including exocytosis, plasma membrane repair, blood coagulation, apoptosis, adhesion, and inflammation (McNeil et al., 2006; White et al., 2006; van Genderen et al., 2008; Blume et al., 2009; Bouter et al., 2011; Draeger et al., 2011). Intriguingly, Anx A1 and A5 are up-regulated during myotube formation in vitro (Arcuri et al., 2002; Tannu et al., 2004; Kislinger et al., 2005; Gonnet et al., 2008; Casadei et al., 2009; Makarov et al., 2009; Bizzarro et al., 2010) and during muscle regeneration in vivo (see the Public Expression Profiling Resource at http://pepr .cnmcresearch.org/). Furthermore, Anx A1 has been implicated in myogenic differentiation and myotube formation (Bizzarro et al., 2010).

In this study, we analyze in vitro myotube formation by $\mathrm{C} 2 \mathrm{C} 12$ and primary mouse myoblasts. We use treatment with lysophosphatidylchloine (LPC) to uncouple the cell-to-cell fusion stage from the earlier stages of myogenesis that prepare the cells for fusion. LPC reversibly blocks the merger of the contacting leaflets of the fusing membranes at the onset of diverse membrane fusion processes (Chernomordik and Kozlov, 2005) so that an LPC block allowed us to accumulate readyto-fuse cells and to observe a relatively synchronized fusion upon LPC removal. We show that antibodies to Anx A1 and A5 and also peptides derived from the N-terminal domain of these Anx (A1- and A5-peptides) inhibit synchronized myoblast fusion and myotube formation in the experiments without LPC application. Myotube formation was also inhibited by siRNA suppression of Anx A1 and A5 expression. Similarly, primary myoblasts isolated from either Anx A1 mutant or Anx A5 mutant mice are deficient for in vitro myotube formation. Reducing both Anx A1 and A5 together inhibits myoblast fusion more effectively than lowering expression of either one of these Anxs alone. Fusion inhibition accomplished by lowering the concentration of one of these Anxs can be rescued by application of a recombinant version of either Anx A1 or A5 (rA1 and rA5). Finally, using our LPC block synchronization system, we also examined events downstream of the Anx-dependent early fusion stages. Syncytium formation was inhibited by ATP depletion and was dependent on dynamin 2 (DNM2) and phosphatidylinositol 4,5-bisphosphate (PtdIns(4,5)P2). These findings can bring valuable insights into mechanisms by which mutations in DNM2 and myotubularin, a protein involved in turnover of phosphoinositides, cause centronuclear myopathies (Spiro et al., 1966; Bitoun et al., 2005; Hnia et al., 2012).

\section{Results}

Experimental system and fusion pathway C2C12 cells and primary myoblasts isolated, if not stated otherwise, from wild-type (WT) mouse were committed to myogenesis by placing them into differentiation medium (DM). To distinguish early fusion intermediates, we complemented syncytium formation assay - the conventional way of quantifying myoblast fusion-with an assay in which we coincubated the cells labeled with green cell tracker and cells labeled with either fluorescent lipid DiI or orange cell tracker to detect either lipid mixing between the cells or an opening of a cytoplasmic connection as the appearance of colabeled cells.

To detect fusion intermediates preceding syncytium formation, we used primary myoblasts after the 12th passage. We found these cells to fuse less effectively than the cells between the 6th and 10th passages used in all other experiments (7\% vs. $20-50 \%$ after $24 \mathrm{~h}$ in DM). We placed the myoblasts of the 12 th passage labeled with green cell tracker and myoblasts labeled with DiI into DM. 24 h later most of the colabeled cells were multinucleated (Fig. 1 B, arrows). However, we also observed a considerable percentage of colabeled mononucleated cells, where the cells labeled with aqueous probe (green cell tracker) acquired membrane probe (Fig. 1 A, bar 1). We observed less of multinucleated cells and more of mononucleated colabeled cells (Fig. $1 \mathrm{C}$, arrows) after $16 \mathrm{~h}$ in DM than after $24 \mathrm{~h}$ in DM. Note that by the time we scored fusion, fluorescent lipids incorporated into the plasma membrane because of their internalization had been mostly labeling intracellular membranes.

In parallel experiments, we incubated primary myoblasts labeled with green cell tracker together with myoblasts labeled with orange cell tracker and found almost no mononucleated cells colabeled with both aqueous probes (Fig. 1 A, bar 2; colabeling was observed only in 3 out of 588 cell pairs and in 1 out of 642 after 16 and $24 \mathrm{~h}$ of incubation in DM, respectively). These findings indicated that myoblast fusion starts with hemifusion (merger of only outer membrane leaflets [Chernomordik and Kozlov, 2005]) and, in contrast to cell fusion mediated by viral fusogens (Chernomordik and Kozlov, 2005), very rarely stalls at a stage of a nonexpanding fusion pore. Note that our experimental approach would not distinguish between bona fide hemifusion and fusion pores too small or too short-lived to allow passage of the cell tracker-labeled proteins.

Further evidence that myoblast fusion proceeds through hemifusion intermediates came from experiments with LPC. In the case of $\mathrm{C} 2 \mathrm{C} 12$ cells, myotubes were first observed $2 \mathrm{~d}$ after the cells were placed in the DM. At this time, we coplated the cells labeled with different fluorescent probes. The next $16 \mathrm{~h}$ were the period of efficient cell fusion, detected as a rise in the percentage of cell nuclei in multinucleated cells (a measure of syncytium formation) and in the number of cells colabeled with both probes (a measure of lipid mixing). Both syncytium formation and lipid mixing were strongly inhibited by the LPCsupplemented DM applied at the start of this 16-h interval. Fusion rapidly ensued when the LPC was washed out at the end of the 16-h incubation (Fig. 1 D, time 0). Within 30 min after replacement of the LPC-supplemented DM with an LPC-free one, the extent of lipid mixing and syncytium formation for $\mathrm{C} 2 \mathrm{C} 12$ cells was approaching the levels observed at this time in the control experiment performed without LPC application.

LPC has also reversibly blocked fusion of primary myoblasts. As with C2C12 cells, LPC removal resulted in a largely synchronous fusion process (Video 1) with a much higher rate of fusion events than the rates observed in cells that had not been exposed to LPC (Video 2). This robust fusion and analysis 
A
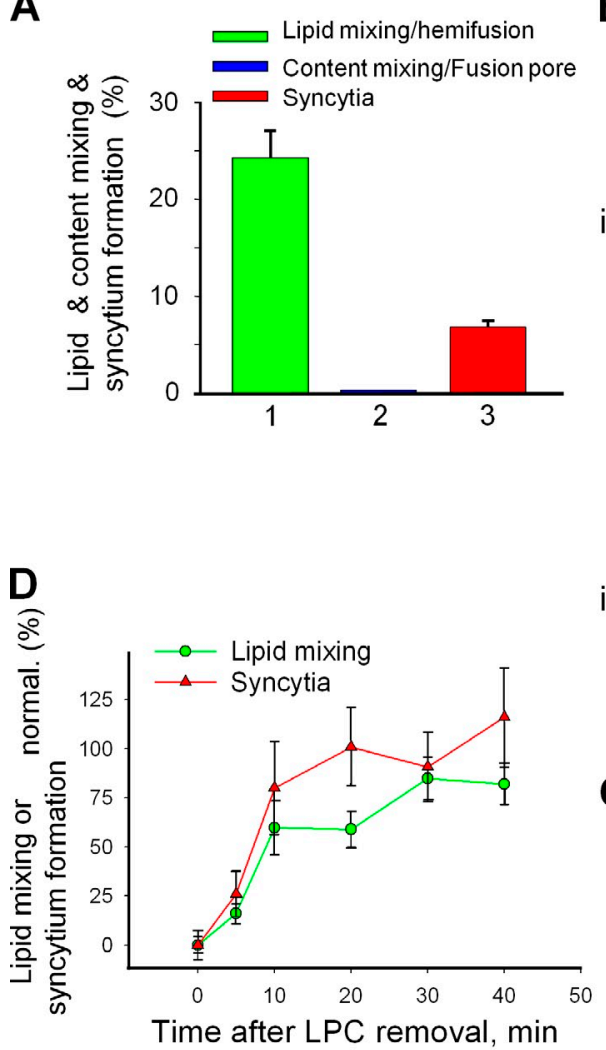

B

Phase contrast \& blue - nuclei

green - cell tracker; red - lipid probe

$16 \mathrm{~h}$

in DM
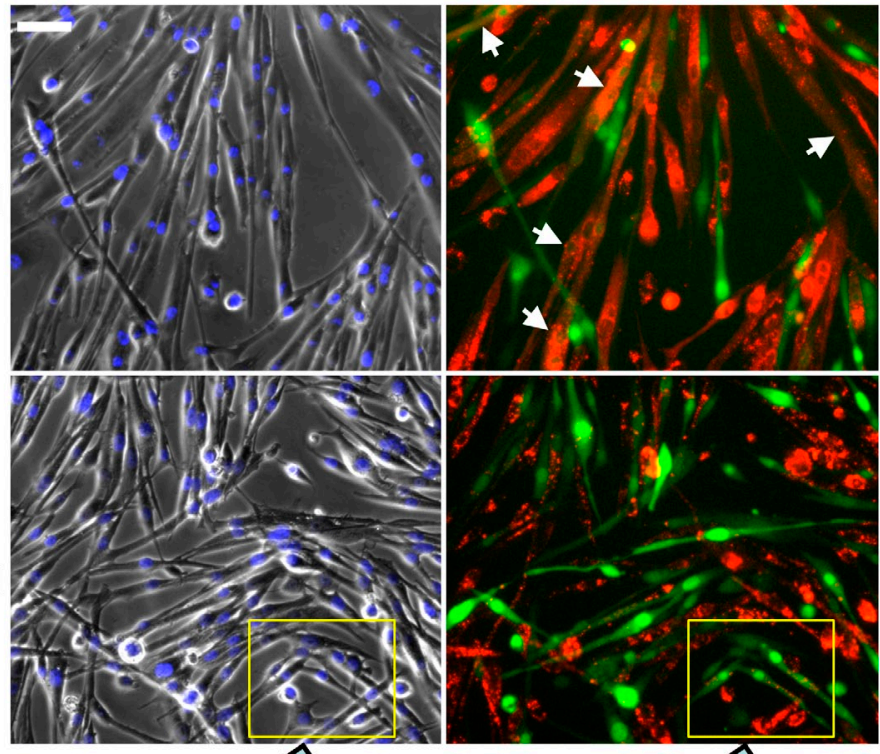

C
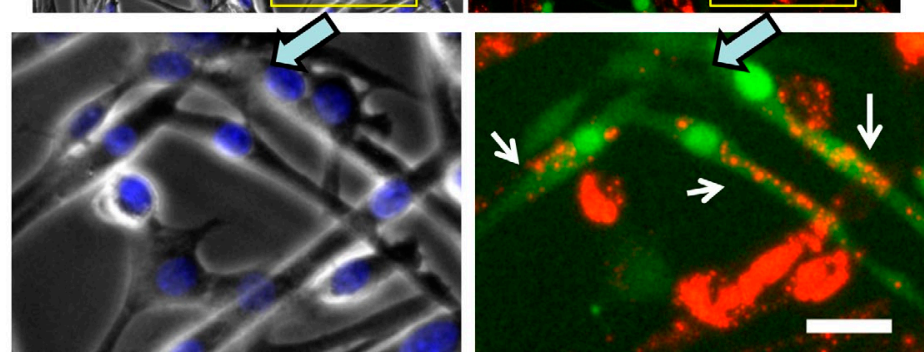

Figure 1. Myoblast fusion proceeds via hemifusion intermediates and is reversibly blocked by hemifusion-inhibiting lipid LPC. (A-C) Fusion phenotypes observed for primary myoblasts of 12th passage after $24 \mathrm{~h}$ (A) and 24 or $16 \mathrm{~h}$ (B) in DM. (A) Percentage of mononucleated cells labeled with green cell tracker that had also acquired red fluorescence by lipid probe exchange with Dil-labeled cells (1) or in parallel experiment (2) by cell tracker exchange with orange cell tracker-labeled myoblasts that signify cytoplasmic connection. (3) Syncytium formation quantified combining the data from the experiments shown in 1 and 2. (B and C) Fluorescence microscopy images illustrating hemifusion phenotype. Left, phase contrast with nuclear staining; right, green cell tracker and Dil (red). (B) Arrows mark the colabeled multinucleated cells. Bar, 50 pm. (C) An enlargement of the marked region in B (bottom) with white arrows pointing to the mononucleated cells colabeled with membrane probe Dil (red) and green cell tracker, a hallmark of the hemifusion phenotype. Bar, $25 \mathrm{~mm}$. (D) LPC inhibited C2C12 cell fusion and concentrated the fusion events that would normally develop within $16 \mathrm{~h}$ to develop mostly within 30 min after LPC removal. Curves show time courses of increase in the extents of lipid mixing (green circles) and syncytium formation (red triangles) after LPC removal at $t=0$ normalized to those observed in the control experiments in which both application of LPC at $t=-16 \mathrm{~h}$ and its removal at $t=0$ were omitted. All results are shown as means $\pm \operatorname{SEM}(n \geq 3)$.

of expression of myogenic markers myogenin and myosin heavy chain (MHC; Fig. S1) indicated that $16 \mathrm{~h}$ in the presence of fusion-inhibiting concentration of LPC did not block myogenic differentiation of the cells.

The finding that LPC reversibly blocks myoblast fusion both supported the fusion-through-hemifusion pathway and provided us with a way to effectively separate the fusion stage from the upstream processes of myogenesis and to concentrate the fusion events that would normally develop within a 16-h span within 30 to $60 \mathrm{~min}$. Combining syncytium formation assay and lipid mixing assay will be used here for distinguishing conditions that affect early and late stages of myoblast fusion.

\section{Myotube formation involves extracellular}

Anx $\mathbf{A} 1$ and $\mathbf{A} 5$

We found myogenic differentiation of primary myoblasts to be associated with a sharp boost in Anx A1 and A5 presence on the cell surface (Fig. 2, A and B). Elevated amounts of both Anxs were also present at the outer surface of $\mathrm{C} 2 \mathrm{C} 12$ cells at the time of myotube formation (Fig. 2 C). To test for a functional role for Anx expression, we incubated differentiating cells with antibodies to Anx A1 and A5. Each antibody inhibited both lipid mixing and syncytium formation in $\mathrm{C} 2 \mathrm{C} 12$ cells and in primary myoblasts (Fig. 2, D and E). Because antibody binding to surface-associated proteins can inhibit fusion by steric hindrance even if the antigens are not involved in fusion, we tested an alternative approach to block Anx A1 and A5 activities by the peptides comprising N-terminal regions of these Anxs. A1-peptide has been demonstrated to inhibit several Anx A1dependent processes (McNeil et al., 2006; Wang et al., 2011). Here we show that this peptide and an A5-peptide inhibited lipid mixing and syncytium formation by primary myoblasts (Fig. 2, G and F).

We confirmed a functional requirement for Anx A1 and A5 in myotube formation by using siRNA (Fig. 3, A and B). Inefficient lipid mixing and syncytium formation associated with Anx A1 suppression were rescued not only by rA1 but also by rA5. Similarly reduced fusion efficiency in cells transfected with A5 siRNA was rescued by rA1 as well as by rA5. Thus both Anxs are involved in myotube formation but shortage of 
A

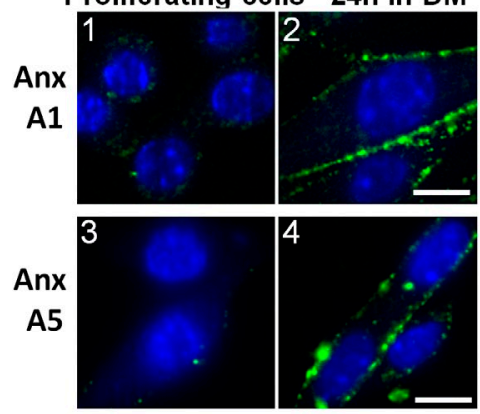

D

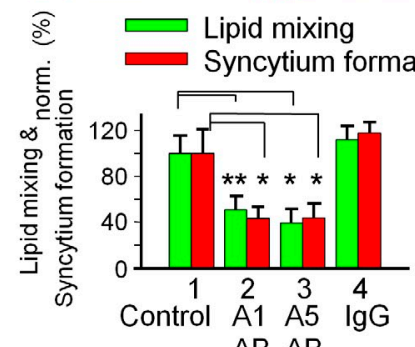

$A B A B$
B

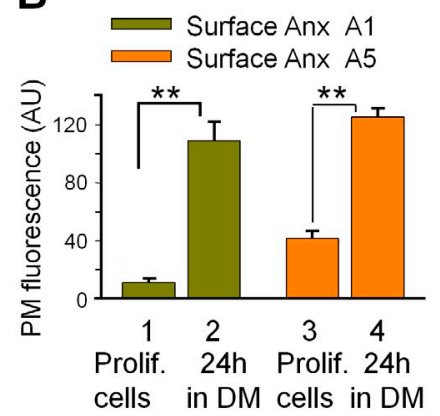

E

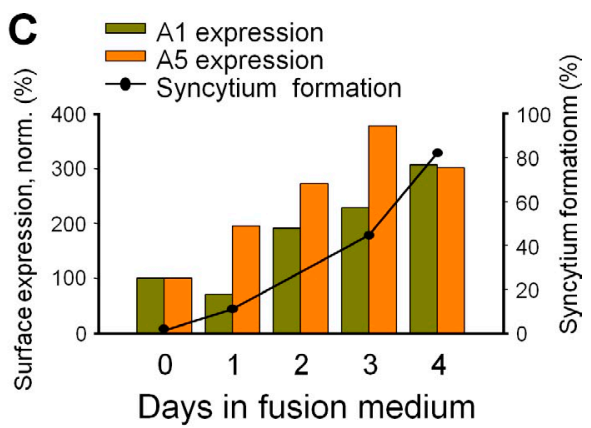

G

F
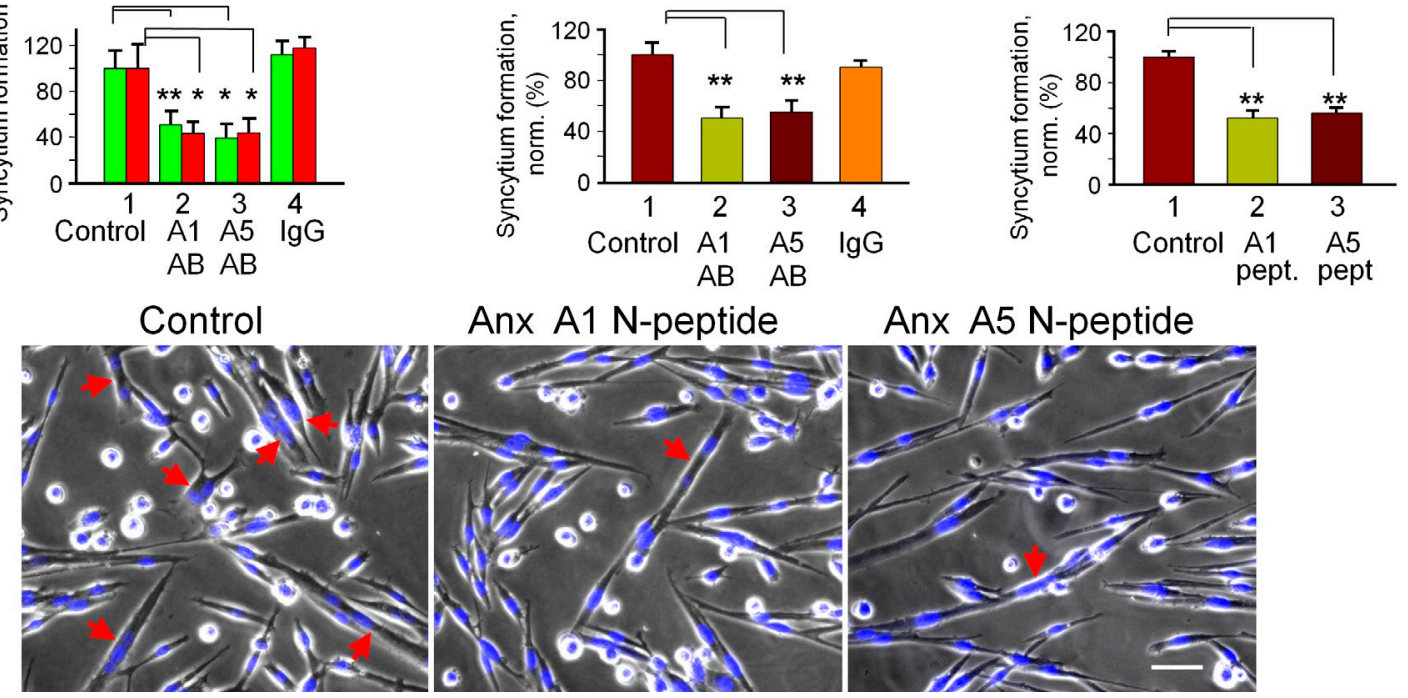

Figure 2. Myotube formation involves extracellular Anx A1 and A5. (A and B) Myogenic differentiation of primary myoblasts boosts surface concentration of $A n \times A 1$ and A5. Anx Al (1 and 2) and A5 ( 3 and 4 ) were detected by immunofluorescence microscopy in nonpermeabilized proliferating cells ( 1 and 3 ) and the cells that were incubated in DM for $24 \mathrm{~h}(2$ and 4$)$. Bars, $10 \mu \mathrm{m}$. (B) Cell surface fluorescence was quantified for 16 cells for each condition and presented as mean \pm SEM. (C) The time course of syncytium formation by $\mathrm{C} 2 \mathrm{C} 12$ cells correlates with a rise in the surface concentration of $\mathrm{Anx} A 1$ and $\mathrm{A} 5$. Anx concentrations are normalized to those at day 0 (at the time of placing the cells in DM). The data shown are from a single representative experiment out of three repeats. For the experiment shown, each point and bar is based on analysis of 10 randomly chosen fields of view. (D and E) Antibodies to A1 and A5 (2 and 3, respectively) inhibit lipid mixing and syncytium formation (D) for C2C12 myoblasts at $67 \mathrm{~h}$ in DM and syncytium formation for primary myoblasts at $24 \mathrm{~h}$ in DM (E). Control experiments with no antibodies applied (1) or with nonspecific lgG (4) are shown. (F and G) Al-and A5-peptides inhibit syncytium formation by primary myoblasts at $24 \mathrm{~h}$ in DM. (F) Phase contrast with nuclear staining (blue) images of the cells incubated or not with either A1- or A5-peptides. Bar, 50 m. Arrows mark the multinucleated cells. (D, E, and G) Lipid mixing and syncytium formation extents are normalized to those in the control experiments (1). All results are means $\pm \operatorname{SEM}(n \geq 3)$. Levels of significance relative to controls $(1):{ }^{*}, \mathrm{P}<0.01 ;{ }^{*}, \mathrm{P}<0.05$.

one can be compensated for by the other, suggesting functional redundancy. Note that not only do rA1 and rA5 rescue fusion, they also promote fusion in $\mathrm{C} 2 \mathrm{C} 12$ cells and WT primary myoblasts (Fig. S2).

The presence of nontransfected cells limits the effects of A1 and A5 siRNAs on total levels of expression of these proteins and on myotube formation. To focus on the transfected myoblasts, we labeled them by cotransfection with GFP vector and scored the efficiency of syncytium formation for only GFPlabeled cells. Lowering the de novo expression of Anx A1 and A5 in the cells transfected with the corresponding siRNAs strongly inhibited their ability to fuse (Fig. 3, C and D). Interestingly, we observed no changes in the fusion efficiency for cells that were not transfected (defined as the cells that did not express GFP) in the same tissue culture plate (Fig. $3 \mathrm{C}$, right) in spite of a considerable decrease of the Anx A1 and A5 contents in the total cell lysates (Fig. 3 B). Thus fusion competence of individual myoblasts depends on the Anx A1 and A5 expressed by these cells rather than on Anx expressed by other cells. These findings suggest that most of the Anx A1 and A5 released by the Anx-expressing cells remain associated with the surfaces of these cells. Note that the amounts of Anx released into the extracellular medium are much lower than the amounts of rA1 and rA5 added exogenously in Fig. 3 A.

To explore the effects of a complete lack of either Anx A1 or A5, we compared the time courses of syncytium formation in primary myoblasts isolated from Anx A1-deficient mice (Hannon et al., 2003), from Anx A5-deficient mouse (Brachvogel et al., 2003), and from the WT parental strain mice. Although primary myoblasts from Anx $\mathrm{A}^{-1-}$ and from Anx $\mathrm{A} 5^{-1-}$ mice incubated in DM for $24 \mathrm{~h}$ expressed myogenic differentiation markers myogenin and MHC similarly to WT myoblasts (Fig. S1), the lack of either of the two Anxs considerably impaired lipid mixing and syncytium formation 

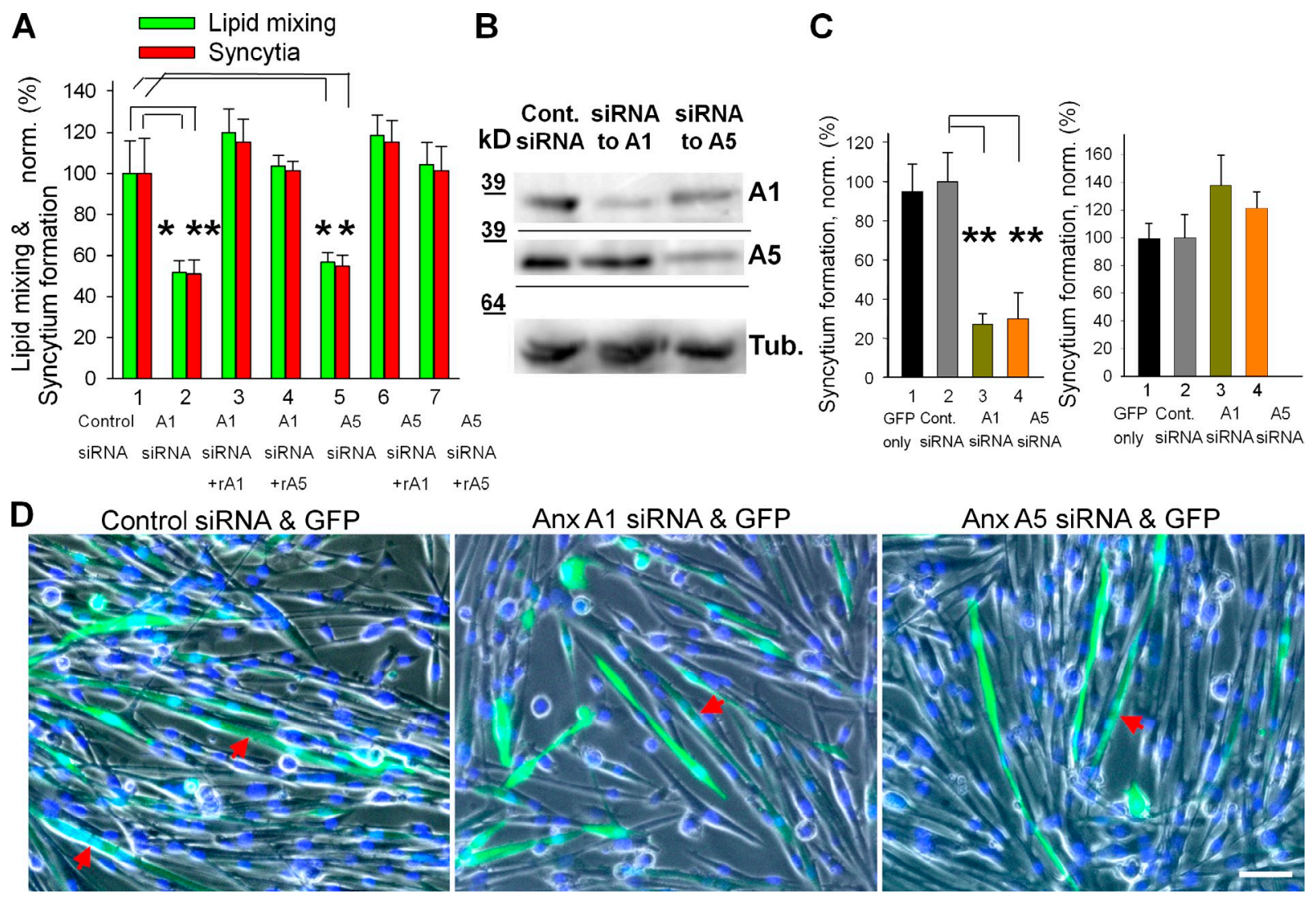

Figure 3. siRNAs targeting expression of $A n x A 1$ or $A 5$ inhibit fusion of primary myoblasts. (A) Inhibition of lipid mixing (green) and syncytium formation (red) at $24 \mathrm{~h}$ in DM by $\mathrm{A} 1$ and $\mathrm{A} 5$ siRNAs is reversed by application of $\mathrm{AA} 1$ or rA5. 1, cells transfected with negative control siRNA; 2-4, cells transfected with A1 siRNA; 5-7, cells transfected with A5 siRNA. rAl (3 and 6) and rA5 (4 and 7) were applied $3 \mathrm{~h}$ before scoring fusion. (B) The cells transfected with control siRNA or A1 or A5 siRNAs were lysed after $24 \mathrm{~h}$ in DM and analyzed by Western blot to evaluate levels of expression of Anx A1 and A5 and tubulin (as a loading control). (C) After cotransfection of primary myoblasts with siRNA and GFP vector, we separately assayed syncytium formation for transfected (left) and not-transfected (right) cells. 1, transfection with GFP vector alone; 2, cotransfecion with GFP vector and negative control siRNA (taken as 100\%); 3 and 4, cotransfection with GFP vector and siRNA to either Anx A1 (3) or A5 (4). (D) Phase-contrast images with nuclear staining (blue) and GFP fluorescence (green) showing myoblasts cotransfected with GFP and control (left), Anx Al (middle), or Anx A5 (right) siRNA. Arrows mark the GFP-labeled multinucleated cells. Bar, $50 \mu \mathrm{m}$. (A and C) All results are shown as means \pm SEM $(n \geq 3)$. Levels of significance relative to controls (1 in $A$ and 2 in $\mathrm{C}$ ) are shown: ${ }^{*}, \mathrm{P}<0.01 ;{ }^{*}, \mathrm{P}<0.05$.

(Fig. 4, A and B). Application of rA1 or rA5 rescued these defects (Fig. 4 C).

Can myotube formation in the absence of either of the two Anxs be explained by redundancy of their functions? We transfected Anx A1 $1^{-1-}$ myoblasts with A5 siRNA constructs and transfected Anx A5 $5^{-1-}$ myoblasts with A1 siRNA constructs. The transfected myoblasts, identified by GFP vector cotransfection, only very rarely joined myotubes (Fig. 4, D and E). As expected, siRNAs targeting Anx A1 in $\mathrm{A}^{-/-}$cells or Anx A5 in $\mathrm{A} 5^{-1-}$ cells had no effect on myotube formation. Thus, in the absence of one of these two Anx, lowered expression of the remaining one almost completely abolishes myotube formation, which is consistent with their being functionally redundant.

To summarize, the dependence of myotube formation on the concentrations and activities of Anx A1 and A5 indicates that these Anxs play an important role in myogenesis.

Anx $A 1$ and $A 5$ at the fusion stage of nyotube formation

To focus on fusion stage we accumulated ready-to-fuse myoblasts using LPC block and applied Anx-targeting reagents at the time of LPC removal. As with myotube formation in the experiments without LPC application, synchronized fusion of $\mathrm{C} 2 \mathrm{C} 12$ cells was inhibited by antibodies to Anx A1 and A5 (Fig. 5, A and B) and by A1- and A5-peptides (Fig. 5 C). In contrast, neither control IgG nor the scrambled versions of the peptides influenced fusion.

Myotube formation requires the presence of $\mathrm{Ca}^{2+}$ in the extracellular environment (Shainberg et al., 1969). EGTA application 30 min before LPC removal inhibited fusion between $\mathrm{C} 2 \mathrm{C} 12$ myoblasts (Fig. $5 \mathrm{D}$ ), indicating that $\mathrm{Ca}^{2+}$ is required for the fusion stage of myogenesis. Because subsequent application of $\mathrm{Ca}^{2+}$-containing medium did not reverse the inhibition by the time we scored fusion, and because chelators were reported to dissociate Anx from cell membranes (Rao et al., 1992; Fan et al., 2004), we hypothesized that $\mathrm{Ca}^{2+}$-free medium washed out functionally important membrane-associated Anxs. Indeed, myotube formation was partially restored when treatment of the cells with EGTA was followed by application of the $\mathrm{Ca}^{2+}$ containing medium supplemented with rA1 or rA5. Fusion was not restored if rA1 and rA5 were applied in the $\mathrm{Ca}^{2+}$-free medium. A decrease in concentrations of Anx A1 and A5 at the surface of 
A
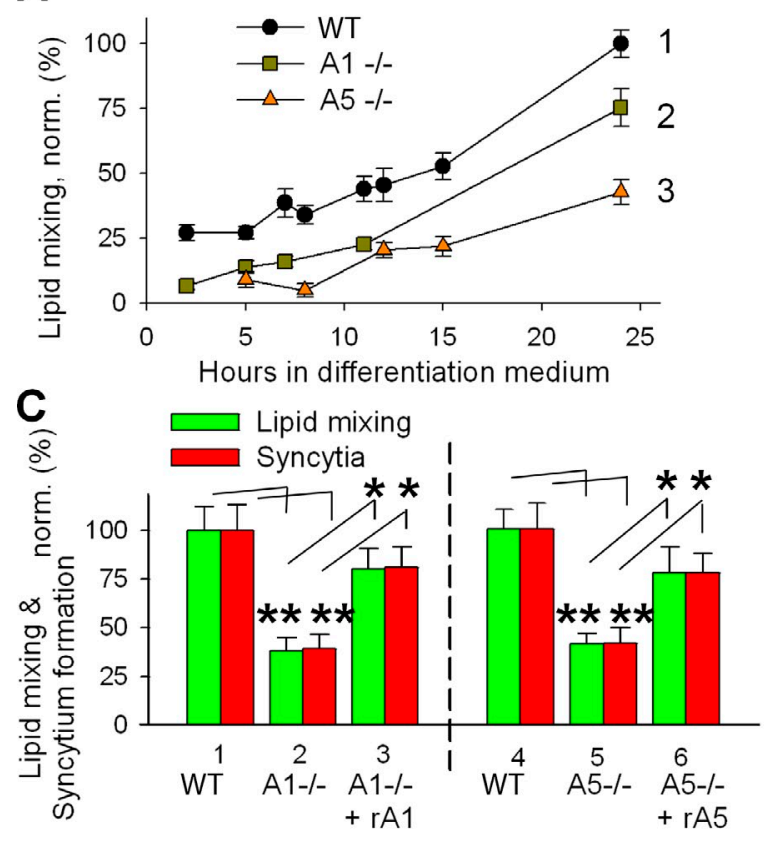

B

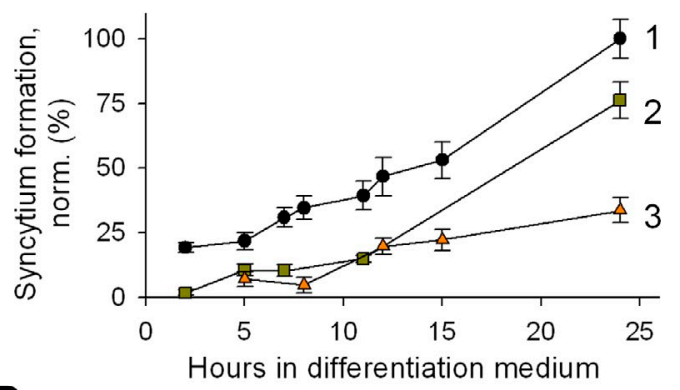

Hours in differentiation medium

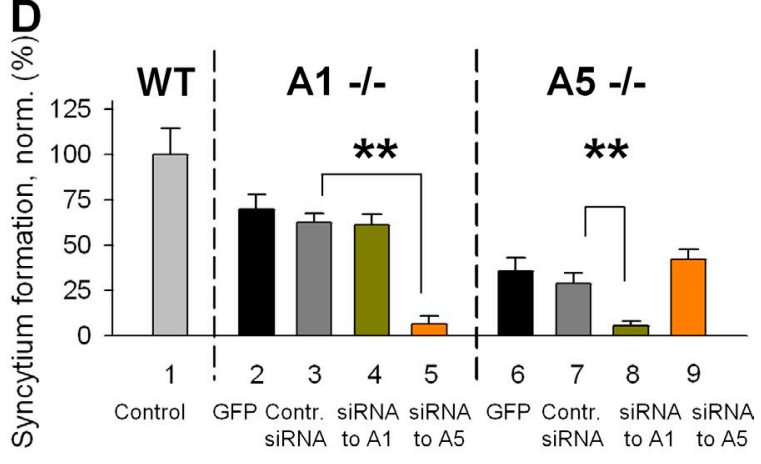

E

Control

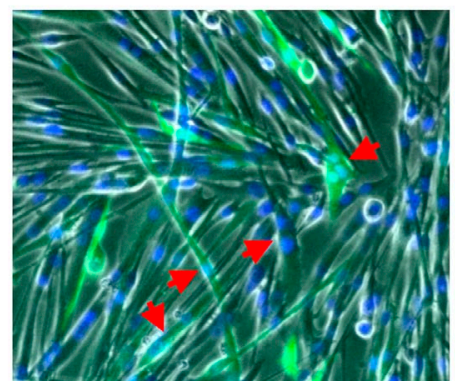

A1-I- \& SIRNA to A5

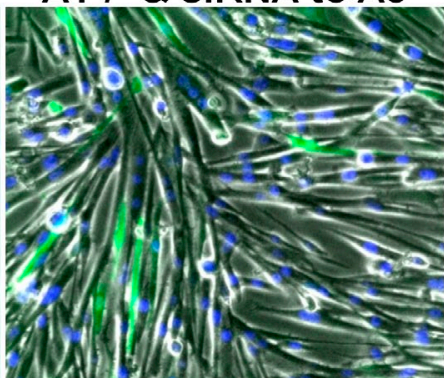

A5-I- \& siRNA to A1

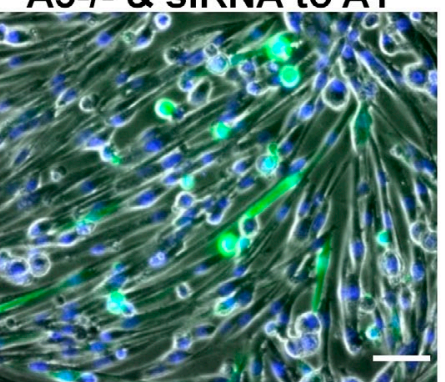

Figure 4. Inhibition of myotube formation for primary myoblasts isolated from either Anx $\mathrm{Al}^{-/-}$or Anx $A 5^{-/-}$mice. (A and $B$ ) The lack of either of the two Anxs substantially inhibited lipid mixing (A) and syncytium formation (B) assayed at different times after placement of the cells into DM (B). Curves show myoblasts isolated from WT mice (1), Anx A1 ${ }^{-1-}$ mice (2), and Anx A5 $5^{-1-}$ mice (3). (C) Application of $\mathrm{rAl}$ or rA5 rescues the fusogenic potential of the Anx-deficient myoblasts. Lipid mixing (green) and syncytium formation (red) at $12 \mathrm{~h}$ after placing WT myoblasts (1) and Anx A ${ }^{-/-}$myoblasts (2) into DM. After $10 \mathrm{~h}$ of incubation of Anx A1 ${ }^{-1-}$ myoblasts in DM, we applied rAl (3). Fusion was assayed $2 \mathrm{~h}$ later. Fusion in 2 and 3 was normalized to fusion in 1. Cell fusion assayed at $14 \mathrm{~h}$ after placement of myoblasts from WT mouse (4) and Anx A5 $5^{-1-}$ myoblasts (5) into DM. After $12 \mathrm{~h}$ of incubation of Anx A5 $5^{-1-}$ myoblasts in DM, we applied rA5 (6). Fusion was assayed $2 \mathrm{~h}$ later. Fusion in 5 and 6 was normalized to fusion in 4 . (D) Myoblasts from $A n \times \mathrm{Al}^{-/-}(2-5)$ or Anx A5 $5^{-/-}$(6-9) were cotransfected with GFP vector and with either control siRNA (3 and 7) or siRNA to Anx Al (4 and 8) or Anx A5 (5 and 9). (2 and 6) Cells transfected only with GFP vector. For each condition, we quantified the efficiency of formation of GFP-labeled syncytia after $24 \mathrm{~h}$ in DM and normalized the results to the efficiency of syncytium formation in WT myoblasts (1). (E) Phase-contrast images with nuclear staining (blue) and GFP fluorescence (green) showing WT myoblasts cotransfected with control siRNA and GFP (left), Anx A1 ${ }^{-1-}$ myoblasts cotransfected with Anx A5 siRNA and GFP (middle), or Anx A5 ${ }^{-1-}$ myoblasts cotransfected with Anx Al siRNA and GFP (right). All cells are after $24 \mathrm{~h}$ in DM. Arrows mark the GFP-labeled multinucleated cells. Bar, $50 \mu \mathrm{m}$. (C and D) All results are shown as means $\pm \operatorname{SEM}(n \geq 3)$. Levels of significance are shown: ${ }^{* *}, P<0.01 ;{ }^{*}, P<0.05$.

myoblasts after EGTA application and the recovery of membrane-associated Anx after the application of $\mathrm{Ca}^{2+}$ and recombinant Anx have been confirmed by immunofluorescence microscopy (Fig. S3). These findings demonstrate that the loss of Anx A1 and A5 at the surface of myoblasts after EGTA application correlates with the loss of fusion activity, and reappearance of the Anxs at the surfaces of the cells after application of rA1 and rA5 rescues the ability of these cells to fuse.

Anx antibodies and peptides also inhibited synchronized fusion between primary myoblasts (Fig. 6, A and B). Moreover, primary myoblasts from Anx A1- and Anx A5-deficient mice demonstrated much less efficient fusion (lipid mixing and syncytium formation) $30 \mathrm{~min}$ after LPC removal than myoblasts from WT mouse (Fig. 6, C and D). A much stronger inhibition of fusion for Anx-deficient myoblasts in these experiments than fusion inhibition observed for the Anx-deficient myoblasts in the experiments without LPC block (Fig. 4, A and B) confirmed that the lack of Anxs inhibited fusion stage of myogenesis. Application of rA1 and rA5 at the time of LPC removal restored the fusogenic potential of the myoblasts (Fig. 6, D and E). These findings indicate that Anx A1 and A5 play a vital role in myoblast fusion.

\section{Transition from lipid mixing to}

syncytium formation depends on cell metabolism, DNMe activity, and Ptdlns 4 ,5]Pe concentration Although Anx-targeting reagents similarly affected lipid mixing and syncytium formation, the ATP-depleting reagents $\mathrm{NaN}_{3}$ 
A
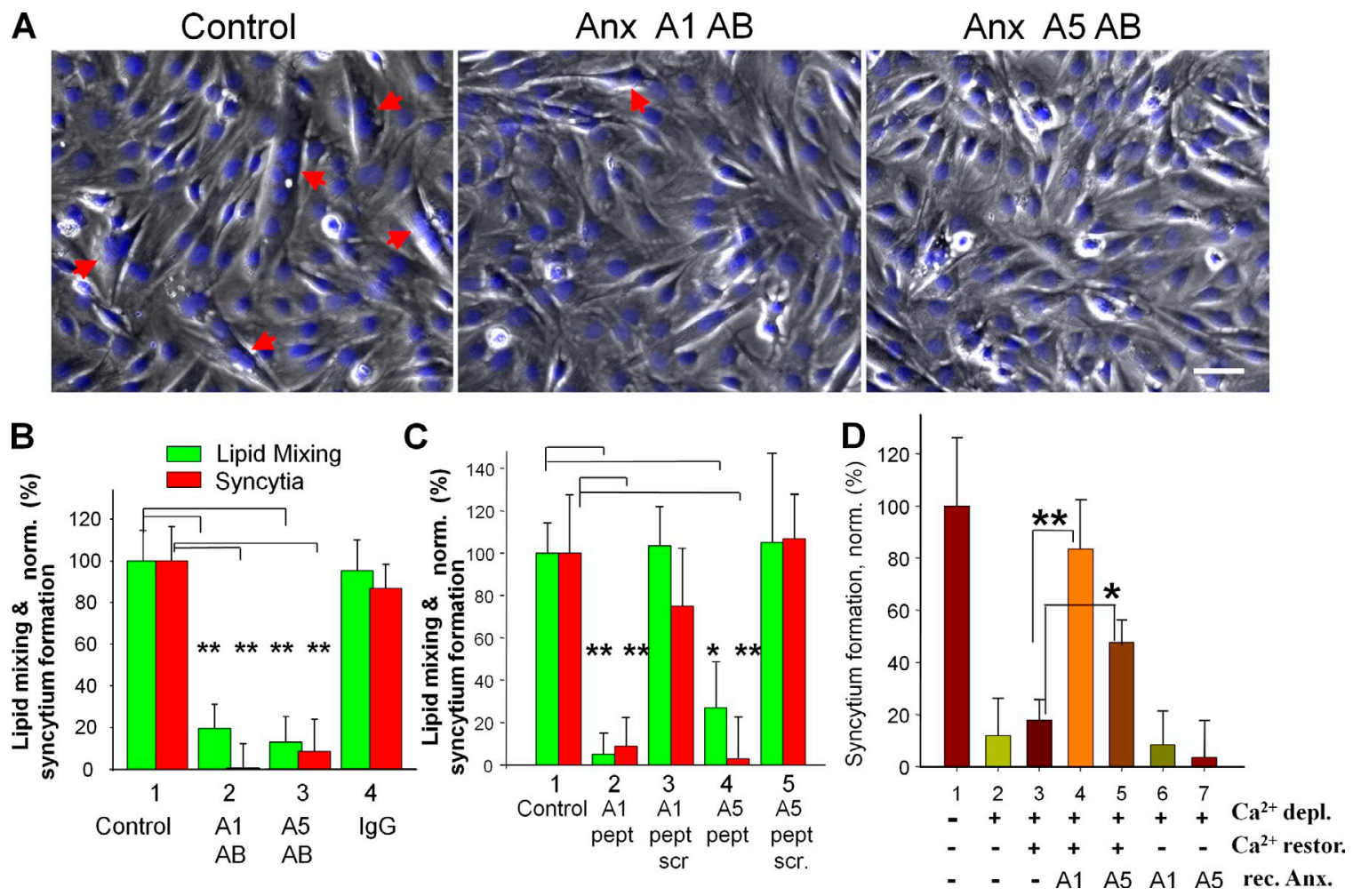

Figure 5. Synchronized fusion of $\mathrm{C} 2 \mathrm{C} 12$ cells is influenced by reagents targeting extracellular Anx A1 and A5. (A) Phase-contrast images with nuclear staining (blue) showing $\mathrm{C} 2 \mathrm{C} 12$ cells that were incubated in DM for $51 \mathrm{~h}$ and then in LPC-supplemented DM for $16 \mathrm{~h}$, and, finally, placed into LPC-free DM (leff) or LPC-free DM with antibodies to Anx Al or A5 (middle and right). The images were taken 30 min after LPC removal. Arrows mark the multinucleated cells. Bar, 50 mm. (B-D) Antibodies (B), A1-and A5-peptides (C), and EGTA (D) were applied to ready-to-fuse myoblasts at the time of LPC removal (B and C) or $30 \mathrm{~min}$ before LPC removal (D). Fusion was scored 30 (B and C) or 60 (D) min after LPC removal and normalized to fusion in the control experiments shown (B-D, 1). (B) Lipid mixing (green) and syncytium formation (red) were inhibited by antibodies to Anx Al (2) and A5 (3) but not by nonspecific lgG (4). 1, untreated cells released from LPC block. (C) Fusion was inhibited by the peptides to Anx A1 (2) and A5 (4) but not by their scrambled versions (3 and 5). (D) At the time of LPC removal, the cells were placed into $\mathrm{Ca}^{2+}$ - and $\mathrm{Mg}^{2+}$-free LPC-free PBS supplemented with 10 mM EGTA (2-7). (3-5) 30 min after LPC removal, we washed the cells with EGTA-free $\mathrm{Ca}^{2+}$ - and $\mathrm{Mg}^{2+}$-containing PBS (3) or with the same buffer supplemented with rA1 (4) or rA5 (5). (6 and 7) As in 4 and 5, but rA1 (6) and rA5 (7) were applied in $\mathrm{Ca}^{2+}$ - and $\mathrm{Mg}^{2+}$-free PBS. (1) At the time of LPC removal, the cells were placed into $\mathrm{Ca}^{2+}$ - and $\mathrm{Mg}^{2+}$-containing PBS. All results are means \pm SEM $(n \geq 3)$. (B-D) Levels of significance relative to 1 in $B$ and $C$ and to 3 in $D$ are shown: $* *, \mathrm{P}<0.01 ; *, \mathrm{P}<0.05$.

and deoxy-D-glucose added to the C2C12 cells (Fig. 7, A and B) or the primary myoblasts (Fig. $7 \mathrm{C}$ ) accumulated at the readyto-fuse LPC-arrested stage 5 min before LPC removal inhibited syncytium formation, but had no effect on lipid mixing.

DNM GTPase is one of many proteins whose function is affected by ATP depletion (Schwoebel et al., 2002). We found that the transition from early to late stages of myoblast fusion for primary myoblasts (Fig. 8, A and B) and C2C12 cells (Fig. S4 A) is blocked by the inhibitors of DNM GTPase dynasore and myristyl trimethyl ammonium bromide (MiTMAB), applied at the time of LPC removal. Interestingly, in the experiments on $\mathrm{C} 2 \mathrm{C} 12$ cells labeled with either green or orange cell trackers, we observed no redistribution of the cell trackerlabeled proteins between the cells treated with DNM inhibitors (Fig. S4 B), suggesting that these inhibitors block fusion at a stage that follows hemifusion (detected as lipid mixing) but precedes formation of fusion pores large enough (a few nanometers in diameter) to pass the labeled proteins.

The importance of DNM2, a DNM isoform expressed in muscles, in late stages of myoblast fusion was confirmed by inhibition of syncytium formation but not lipid mixing observed for primary myoblasts transfected with DNM2 siRNA (Fig. 8, C-E).
Note that DNM2 siRNA experiments were performed without application of LPC.

Myotube formation was also inhibited by two treatments targeting PtdIns(4,5)P2, an important regulator of many intracellular processes including DNM function. The cell-permeant polyphosphoinositide-binding peptide PBP10 binds to PtdIns $(4,5) \mathrm{P} 2$ in the inner leaflet of the plasma membrane and displaces cytosolic PtdIns(4,5)P2-binding proteins (Cunningham et al., 2001). PBP10 applied to myoblasts accumulated at the LPC-arrested stage at the time of LPC removal strongly inhibited syncytium formation but not lipid mixing (Fig. 9, A and B). We observed similar effects after treating the cells with the primary alcohol 1-butanol (Fig. 9 C). This alcohol (but not its isomers t-butanol and 2-butanol) lowers the concentration of phosphatidic acid and thus inhibits the activity of phosphoinositide 5-kinase, which generates PtdIns(4,5)P2 (Boucrot et al., 2006). Note that phosphatidic acid is an important signaling lipid and thus we cannot exclude 1-butanol effects that are independent of PtdIns(4,5)P2.

In brief, late fusion stages that generate multinucleated myotubes depend on cell metabolism, DNM2 GTPase activity, and PtdIns(4,5)P2 content. Because the ATP-depleting reagents, 

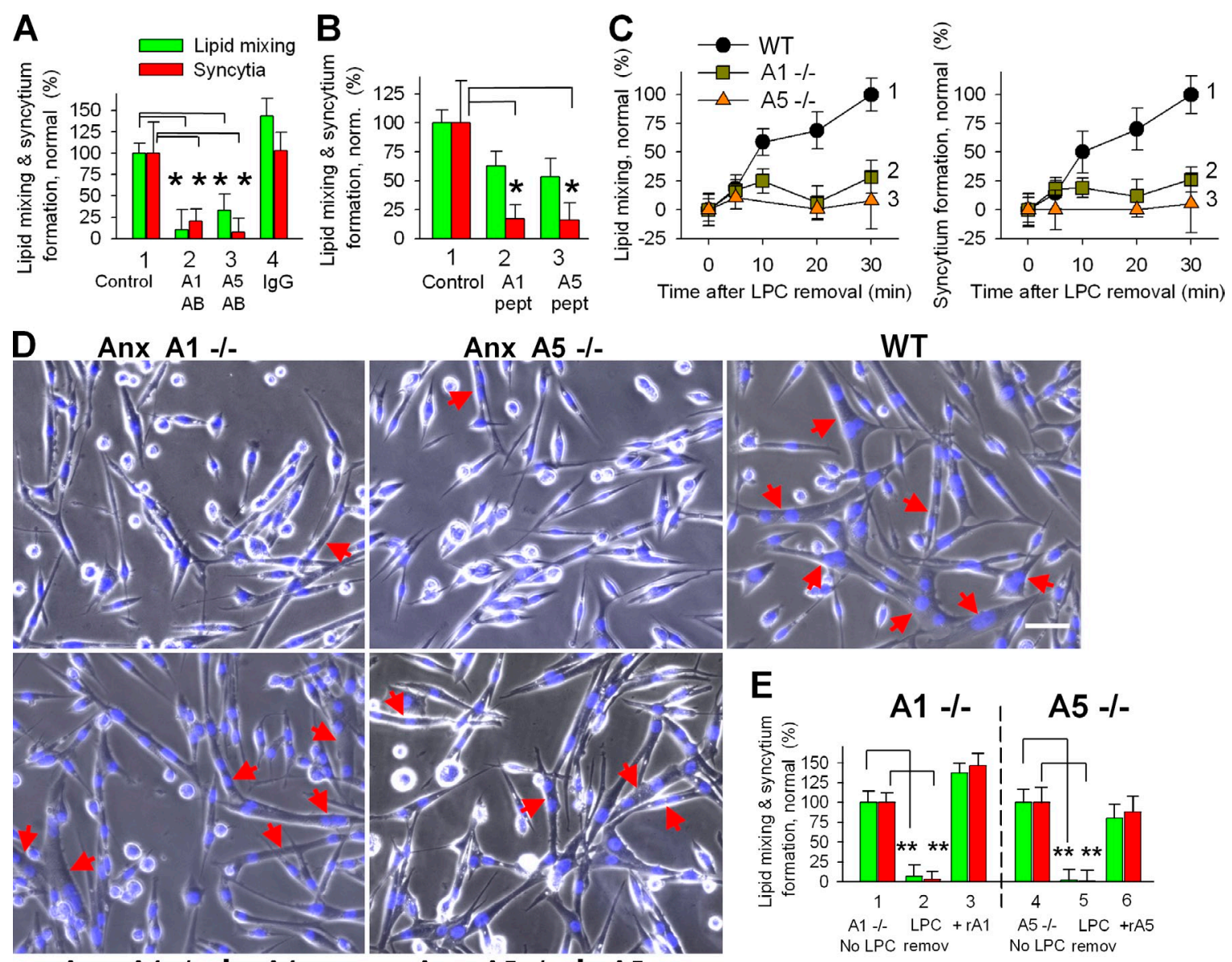

Anx A1 /- + rA1
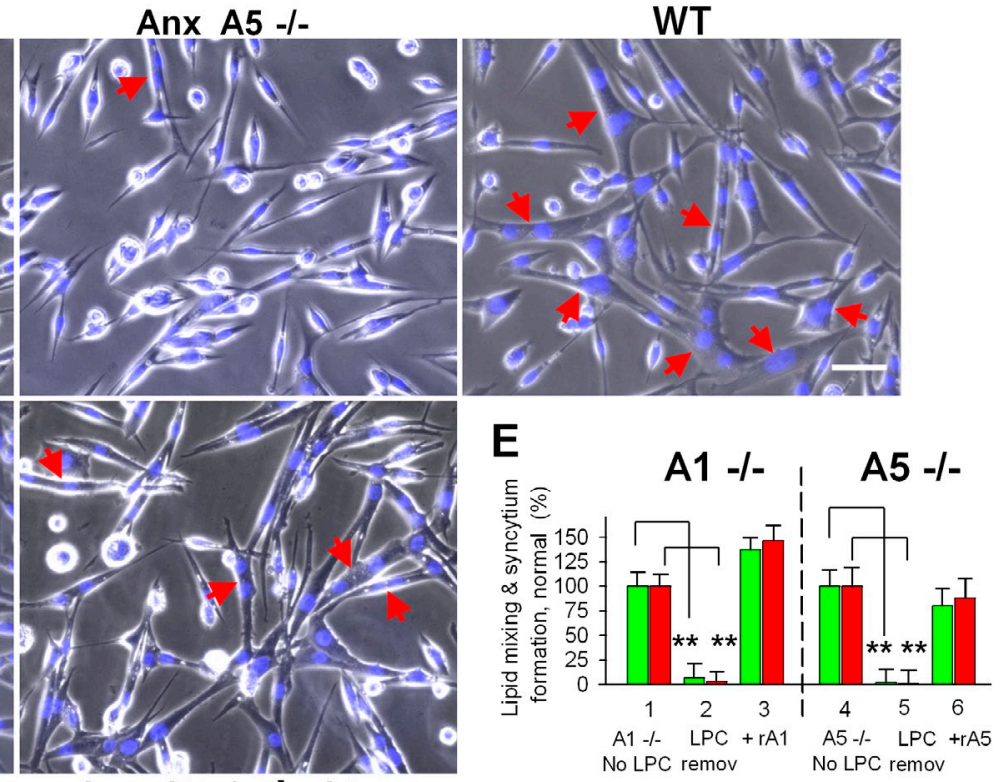

Figure 6. Synchronized fusion of primary myoblasts is inhibited by antibodies, A1- and A5-peptides, and the lack of either of these Anxs. (A) Antibodies to $A n x A 1$ (2) or A5 (3) or nonspecific lgG (4) were applied at the time of LPC removal. (1) Cells released from LPC block with no immunoglobulins added. (B) A 1- and A5-peptides (2 and 3) were applied at the time of LPC removal. (A and B) Lipid mixing (green) and syncytium formation (red) were scored 30 min after LPC removal and normalized to those in the control experiments (1). (C) The extents of lipid mixing (left) and syncytium formation (right) observed at different times after $\mathrm{LPC}$ removal at $t=0$ for WT, Anx A1 ${ }^{-1-}$, and $\mathrm{Anx} A 5^{-/-}$(curves 1,2, 3, respectively) myoblasts. (D) Phase-contrast images with

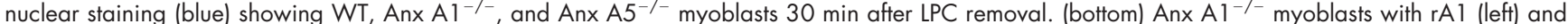
Anx $\mathrm{A5}^{-/-}$myoblasts with rA5 (right). Anxs were applied at the time of LPC removal. Arrows mark the multinucleated cells. Bar, $50 \mu \mathrm{m}$. (E) rA1 and rA5 restore fusogenic potential of Anx-deficient myoblasts. Lipid mixing (green) and syncytium formation (red) in $A n \times A 1^{-1-}(2$ and 3$)$ or $A n \times A 5^{-1-}(5$ and 6$)$ myoblasts were scored 30 min after LPC removal in the absence (2 and 5) or in the presence of rAl (3) or rA5 (6). Fusion extents were normalized to those observed for $A n \times \mathrm{Al}^{-1-}$ (1) and $\mathrm{Anx} \mathrm{A5}^{-1-}$ (4) myoblasts $24 \mathrm{~h}$ after placement of the cells into DM in the experiments in which myogenesis was not interrupted by LPC. All results are shown as means \pm SEM $(n \geq 3)$. Levels of significance relative to corresponding controls ( 1 in $A$ and B and 1 or 4 in E) are shown: ${ }^{*}, \mathrm{P}<0.01 ;{ }^{*}, \mathrm{P}<0.05$.

DNM inhibitors, and PtdIns(4,5)P2-targeting reagents that we used here are known to act very fast, the finding that lipid mixing is not affected by any of these treatments suggests that by the time of fusion, the protein machinery that mediates early fusion stages is located at the cell surface and is not very sensitive to changes in intracellular conditions.

\section{Discussion}

In this work, we uncoupled the fusion stage of myotube formation from the preceding stages of myogenesis that prepare the muscle precursor cells for fusion. We dissected the pathway of myoblast fusion into two stages controlled by different protein machineries (Fig. 9 D). Extracellular Anx A1 and A5, and/or possibly their protein partners, merge two membranes with a lipid connection, allowing the mixing of the membrane lipids of the outer leaflets of the membranes. Intriguingly, this early hemifusion stage is not affected by several reagents targeting cell metabolism, DNM activity, and lipid regulators of cell function: PtdIns(4,5)P2 and phosphatidic acid. In contrast, later fusion stages (a merger of the inner leaflets of the membranes to form a fusion pore or expansion of this pore) are blocked for ATP-depleted cells and involve DNM and PtdIns(4,5)P2.

Our findings suggest that myoblast fusion starts with hemifusion. We blocked this stage by supplementing the outer leaflets of the membranes with LPC known to block mammalian myoblast fusion (Reporter and Raveed, 1973). The finding that the extents of myoblast fusion within 30-60 min after LPC removal approach the levels observed in the experiments performed without LPC application confirmed the reversibility of the LPC inhibition. Because all reagents and treatments that we found to affect the myoblast fusion after lifting LPC block also affected myotube formation in the experiments without LPC 
A
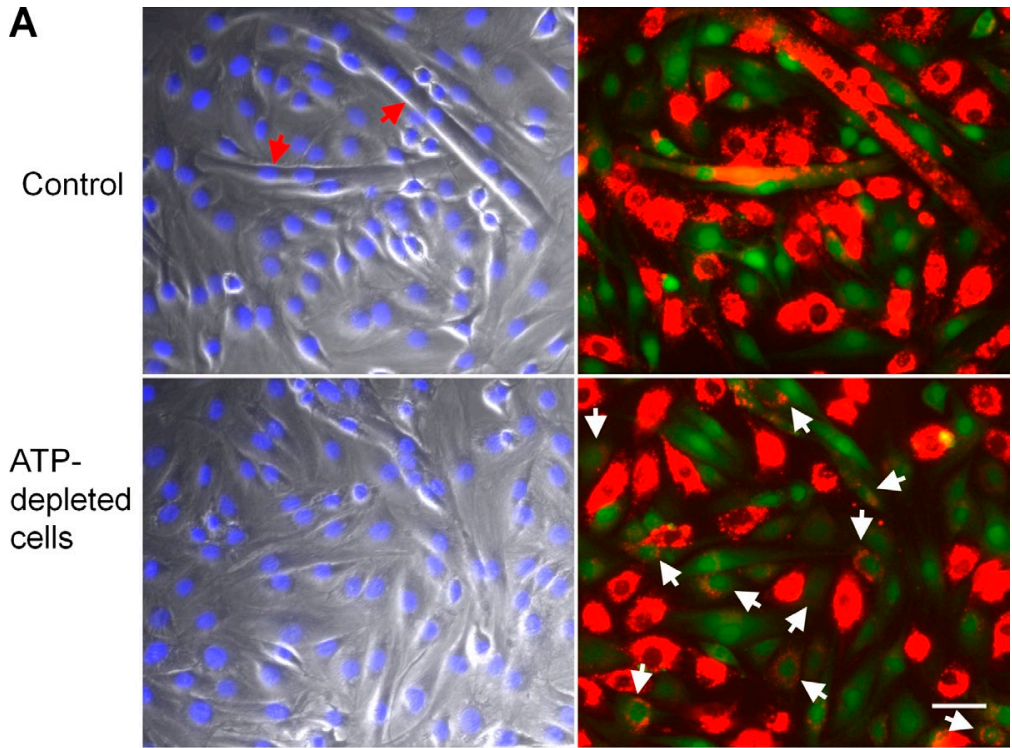

B

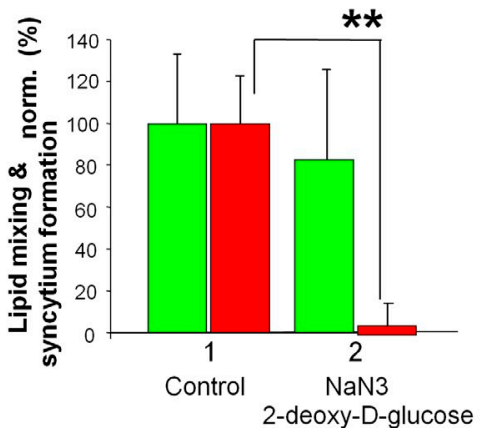

Figure 7. The transition from lipid mixing to syncytium formation depends on cell metabolism. (A and B) A mix of $\mathrm{NaN}_{3}$ and 2-D-deoxyglucose was applied to fusion-committed C2C 12 cells 5 min before LPC removal. (A) Images of the cells treated (bottom) and untreated (top) with ATP-depleting mix were taken 30 min after LPC removal. Left, phase contrast with nuclear staining; right, Dil (red) and green cell tracker. Red and white arrows mark the multinucleated cells and colabeled mononucleated cells, respectively. Bar, $50 \mu \mathrm{m}$. (B and C) In contrast to lipid mixing (green), syncytium formation (red) is blocked by ATP depletion for both $\mathrm{C} 2 \mathrm{C} 12$ cells (B) and primary myoblasts (C). Fusion extents for the ATP-depleted cells (2) were normalized to those for the untreated cells released from LPC block (1). All results are shown as means \pm SEM $(n \geq 3)$. Levels of significance relative to controls (1) are shown: ${ }^{* *}, \mathrm{P}<0.01$ application, it is unlikely that LPC modifies rather than merely blocks the fusion pathway. LPC has been reported to inhibit many disparate membrane fusion processes (Chernomordik and Kozlov, 2005), and thus synchronization of cell fusion using reversible LPC block can be of help in uncoupling the fusion stage from the stages that prepare the cells for fusion in other developmental processes.

The cell machinery that drives the expansion of nascent membrane connections remains to be identified for any cellto-cell fusion process. Our findings indicate that the transition from early hemifusion connections between myoblast membranes to opening and expansion of fusion pores is dependent on cell metabolism and controlled by intracellular machinery. As in cell-to-cell fusion mediated by viral fusogens (Richard et al., 2011), late stages of myoblast fusion involve DNM GTPase and are inhibited by lowering of the membrane concentration of accessible PtdIns(4,5)P2. Our findings are consistent with earlier ones that contact zones between $\mathrm{C} 2 \mathrm{C} 12$ cells at the time of fusion are enriched in PtdIns(4,5)P2 (Nowak et al., 2009) and that a decrease in PtdIns(4,5)P2 content inhibits myotube formation (Bach et al., 2010). Our work identifies the PtdIns(4,5)P2-dependent stage of myoblast fusion as the one downstream of a local membrane merger. PtdIns(4,5)P2 can influence myotube formation by regulating DNM activity or the function of numerous other PtdIns(4,5)P2 binding proteins such as GRAF1, which is implicated in myoblast fusion (Doherty et al., 2011). Although the specific mechanisms by which DNM and PtdIns(4,5)P2 control syncytium formation remain to be identified, our work uncovers the existence of a controlling mechanism that determines whether early fusion connections expand to generate a multinucleated myotube.

The initial merger of myoblast membranes involves extracellular Anx A1 and A5. We found elevated concentrations of these Anxs at the outer surface of murine myoblasts at the time of fusion. Recombinant Anxs promoted myoblast fusion and thus facilitated fusion of cells that would normally not fuse by this time. In contrast, antibodies and A1- and A5- peptides, as well as lowering or abolishing the expression of either of these Anxs, inhibited myoblast fusion. All these modifications of the Anx activity had much stronger effects on the synchronized myoblast fusion than on myotube formation in the experiments without LPC application, and at earlier times after placement of the cells into DM than at the later times. These differences most likely reflect the fact that under normal conditions the cell fusion step takes a small fraction of the total time in DM required for myotube formation.

Although our results suggest the important role of Anx A1 and A5 in myoblast fusion and myogenesis, Anx A1(Hannon et al., 2003), Anx A5- (Brachvogel et al., 2003), and both Anx A5- and A6-deficient mice (Belluoccio et al., 2010) are viable and fertile. None of those studies reported any alterations in the development of the musculoskeletal system 
Figure 8. In contrast to lipid mixing, syncytium formation by primary myoblasts depends on DNM activity. (A and B) After incubation for $16 \mathrm{~h}$ in LPC, cells were washed to remove LPC block to cell fusion and then treated immediately with vehicle (DMSO) as a control or with DNM inhibitors (100 $\mu$ M dynasore or $10 \mu \mathrm{M}$ MitMAB). (A) Images of the cells treated with either dynasore (middle) or MitMAB (right) and vehicle-treated cells (left) were taken 30 min after LPC removal. (top) Phase contrast with nuclear staining; red arrows mark the multinucleated cells. (bottom) Dil (red) and green cell tracker; white arrows mark the colabeled mononucleated cells. Bar, 50 um. (B) 50 and $100 \mu \mathrm{M}$ dynasore (2 and 3 ) and 2.5 and $10 \mu \mathrm{M}$ MitMAB (4 and 5) inhibit syncytium formation (red) but do not inhibit lipid mixing (green). Fusion extents were normalized to those for the vehicle-treated cells released from LPC block (1). (C) Syncytium formation (red) and lipid mixing (green) for myoblasts transfected with control siRNA (1), with 50 (2), and with 100 (3) pM of DNM2 siRNA. Fusion extents were assayed after $40 \mathrm{~h}$ in DM and normalized to those for the cells transfected with control siRNA (1). (B and C) All results are shown as means \pm SEM $(n \geq 3)$. Levels of significance relative to controls (1) are shown: ${ }^{*}, \mathrm{P}<$ $0.01 ;{ }^{*}, \mathrm{P}<0.05$. (D) The cells transfected with control or DNM2 siRNAs were lysed after $40 \mathrm{~h}$ in DM and analyzed by Western blotting to evaluate levels of expression of DNM2 and tubulin (a loading control). (E) Images of the cells transfected with $100 \mathrm{pM}$ of the control siRNA ( 1 and 2 ) and DNM2 siRNA ( 3 and 4 ). Images were taken after $40 \mathrm{~h}$ in DM. Images 1 and 3 show phase contrast with nuclear staining (blue) and images 2 and 4 show Dil (red) and green cell tracker. Red arrows (1 and 3) and white arrows (4) mark the multinucleated cells and colabeled mononucleated cells, respectively. Bar, $50 \mu \mathrm{m}$.
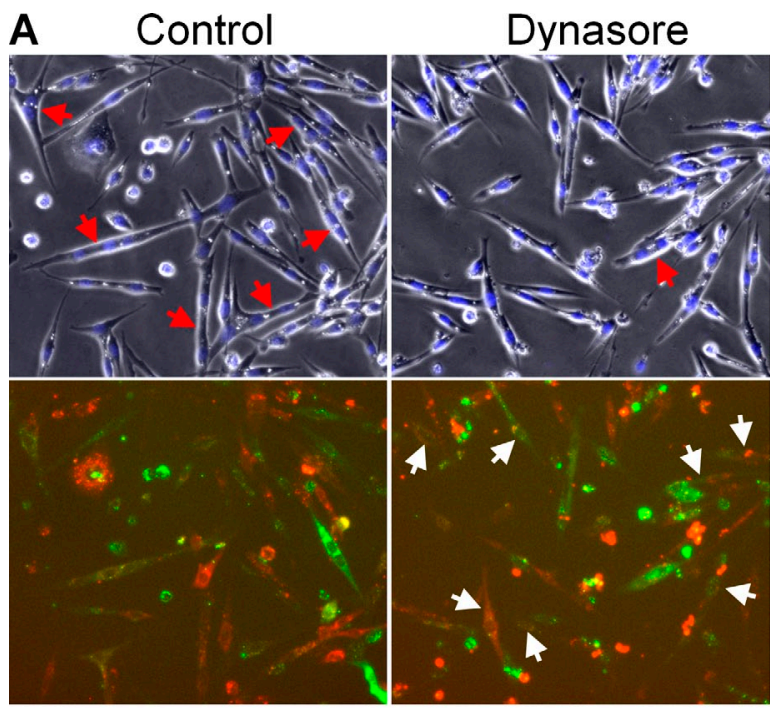

B

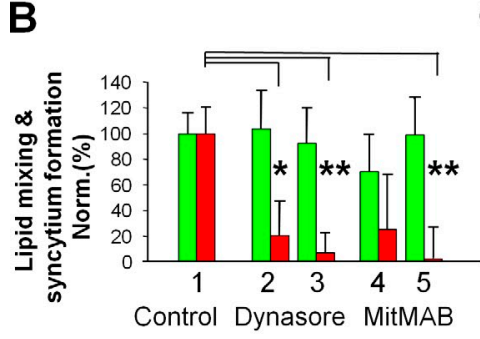

C
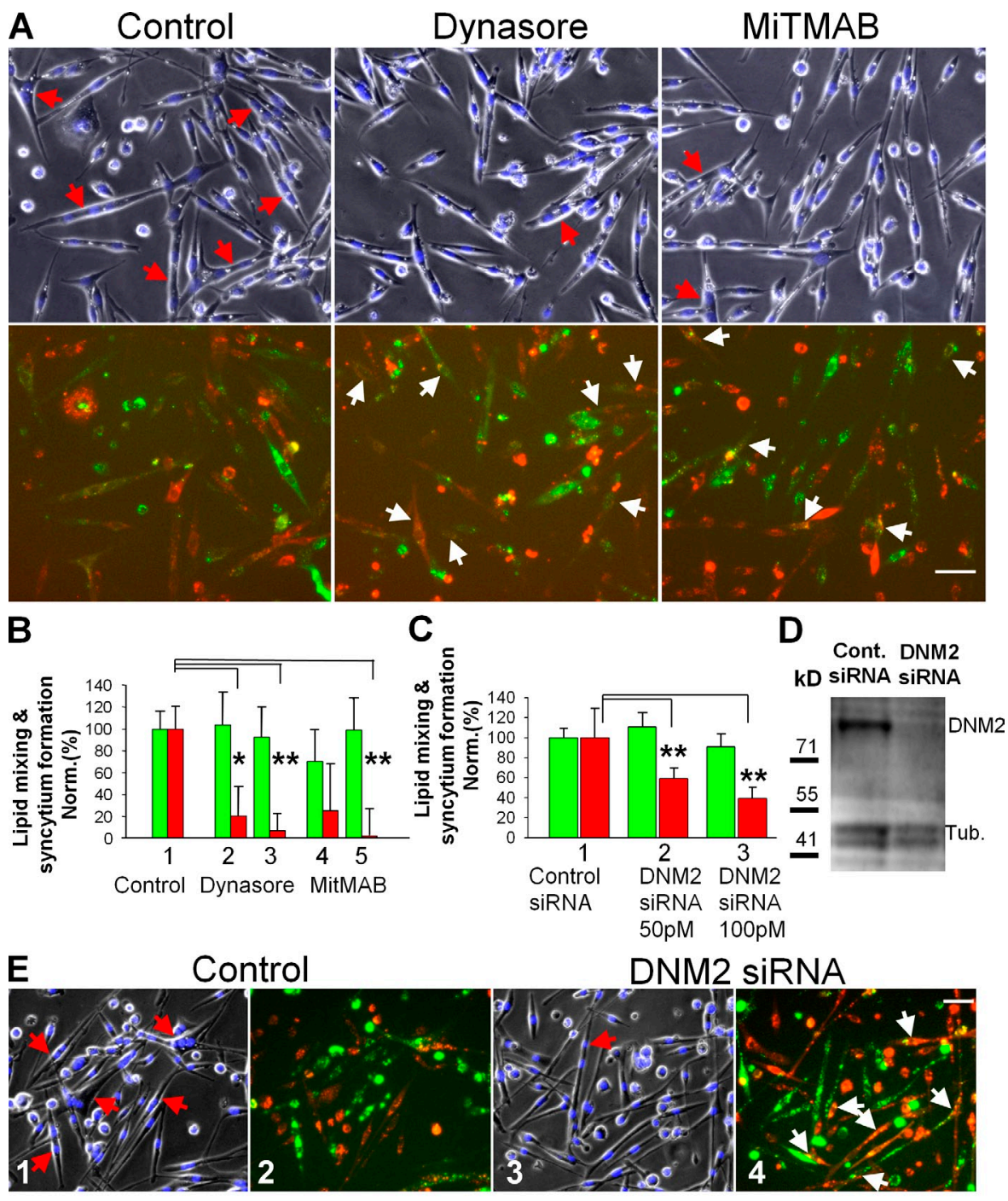

D

DNM2 siRNA
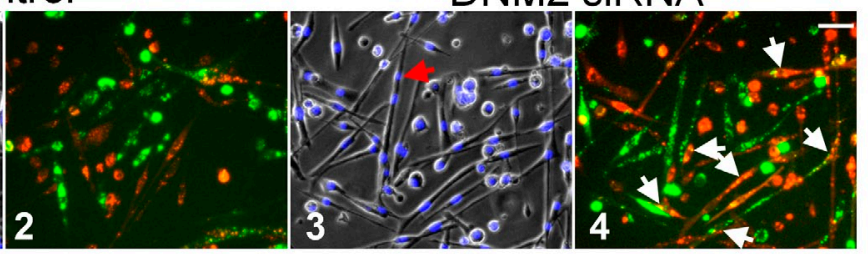

and specifically examined any characteristics of skeletal muscle. In our experiments, the lack of Anx A1 or A5 substantially inhibited synchronized myoblast fusion and slowed down myotube formation, but did not completely block either process, suggesting a functional redundancy between these Anxs. Indeed, we found that a shortage of one of these Anxs can be compensated for by application of a recombinant version of another one. Furthermore, transfecting Anx $\mathrm{A} 1^{-1-}$ myoblasts with A5 siRNA, or vice versa, and transfecting Anx A5 $5^{-l-}$ myoblasts with A1 siRNA resulted in a very potent inhibition of myotube formation. Although our work has focused on the contributions of Anx A1 and A5 in murine myoblast fusion, other representatives of the Anx family are also expressed in fusing myoblasts (Clemen et al., 1999; Tannu et al., 2004; Kislinger et al., 2005) and can be involved in fusion, especially in the absence of either A1 or A5 and for other animals (Duan, 2008). We have systematically studied only Anx A1 and A5 but found that siRNA knockdown of Anx A2 did not inhibit myotube formation for Anx A1 ${ }^{-1-}$ myoblasts (Fig. S5 A), suggesting that Anx A2 does not play an important role in fusion in murine myoblasts.
Anx-dependent myoblast fusion is likely regulated by PS exposure, by an increase in the local concentration of membrane-bound Anx A1 and A5, and/or by mechanisms establishing close cell contacts. Anx A1 and A5 interact with many cell surface proteins (Moss and Morgan, 2004) and can control myoblast fusion by influencing the activities of other, as yet unidentified, proteins. Alternatively, Anxs can directly mediate membrane fusion. Indeed some Anxs, including A1, have been implicated in intracellular fusion processes (Kubista et al., 2000; McNeil et al., 2006) and are known to aggregate and fuse PS-containing liposomes (Francis et al., 1992; Bitto and Cho, 1999). Because Anx A5, on its own, is inefficient in inducing liposome aggregation and lipid mixing (Hoekstra et al., 1993; Bitto and Cho, 1999), fusogenic activity of this Anx can depend on membrane-membrane binding mediated by other proteins, as reported for reovirus fusion machinery (Salsman et al., 2008).

Some prefusion stages of myogenesis may also depend on Anxs (Bizzarro et al., 2010) and be disrupted by an excess of extracellular Anx (van den Eijnde et al., 2001; Kaspar and Dvorák, 2008; Jeong and Conboy, 2011). We also found that 
A

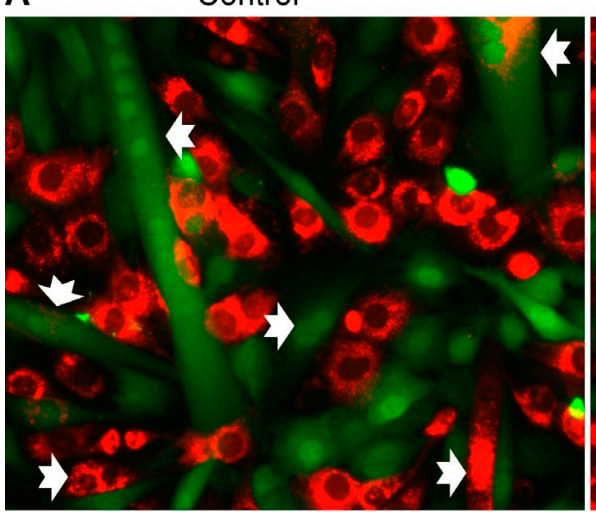

B

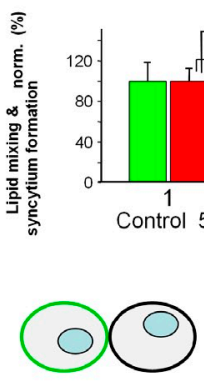

Contact
$* *$

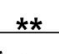

PBP10

C $\overline{8}$

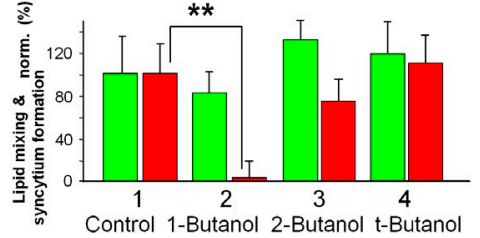

Dynamin- and PIP2-

dependent machinery

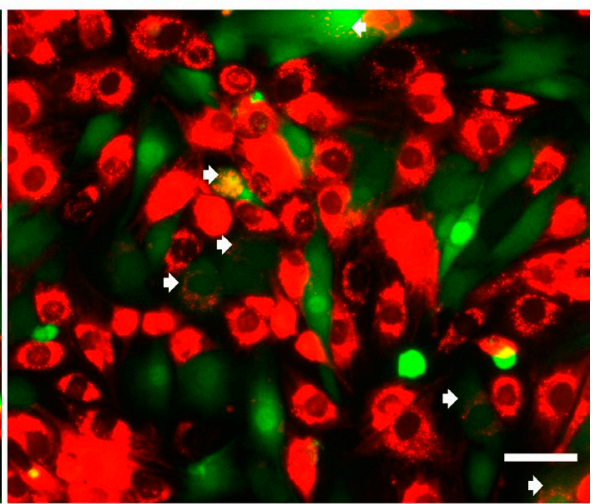

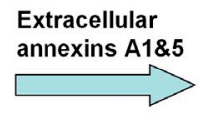

Local membrane merger
Figure 9. The transition from lipid mixing to syncytium formation by $\mathrm{C} 2 \mathrm{C} 12$ cells depends on Ptdlns(4,5)P content. (A) Images of the fusion-committed cells accumulated by LPC block treated with Ptdlns (4,5)P-binding PBP10 $(7.5 \mu M)$ applied at the time of LPC removal (right) or the untreated cells released from LPC block (left). Images show Dil (red) and green cell tracker fluorescence and were taken 30 min after LPC removal. Notched arrows mark the multinucleated cells and smaller arrows mark the colabeled mononucleated cells. Bar, $50 \mu \mathrm{m}$. (B and C) Reagents lowering the concentration of accessible Ptdlns(4,5)P2 in the plasma membrane inhibit fusion of $\mathrm{C} 2 \mathrm{C} 12$ myoblasts assayed as lipid mixing (green) and myotube formation (red). We applied 5 and $7.5 \mu \mathrm{M}$ PBP10 (B, 2 and 3 ) as well as $1 \%$ 1-butanol and, in the control experiments, its inactive isomers 2-butanol and t-butanol (C, 2,3 , and 4 , respectively) at the time of LPC removal. Lipid mixing and syncytium formation extents were normalized to those for the untreated cells released from LPC block (B and C, 1 ; presented as means \pm SEM; $n \geq 3$ ). Levels of significance relative to controls (1) are shown: ${ }^{*}, \mathrm{P}<0.01 ;{ }^{*}, \mathrm{P}<0.05$. (D) The proposed pathway of the fusion stage of myotube formation. Anx Al and A5 at the PS-exposing surface of fusion-committed myoblasts directly or via other proteins initiate membrane merger. Subsequent stages of syncytium formation are controlled by DNM- and Ptdlns(4,5)P2-dependent intracellular protein machinery. application of rA1 or rA5 at the time of placement of the cells into DM rather than later, as in the experiments presented here, inhibited rather than promoted myotube formation.

Earlier work has indicated that formation of multinucleated myotubes is accompanied by changes in membrane concentrations of some lipids (e.g., cholesterol and polyphosphoinositides; Wakelam, 1985), in fatty acid contents of the membranes (Yin et al., 2009), in lipid domain organization of the plasma membrane (Mukai et al., 2009), and in the distribution of some lipids (e.g., PS) between different leaflets of plasma membrane (van den Eijnde et al., 2001). Our findings further emphasize the importance of membrane lipids in the cell fusion stage of myogenesis, suggesting that PS exposure recruits extracellular proteins involved in fusion, LPC blocks membrane merger, and PtdIns(4,5)P2 controls late stages of fusion.

Some of the features of myoblast fusion that are essential for Anx-involving fusion processes have also been reported for other developmental cell-cell fusion processes. Macrophage fusion in giant cell and osteoclast formation, sperm-egg fusion, and cytotrophoblast fusion in placental morphogenesis all involve transient exposure of PS in the outer leaflet of the plasma membrane and depend on extracellular $\mathrm{Ca}^{2+}$ (Yanagimachi, 1978; Jin et al., 1990; Gauster and Huppertz, 2008). Although it is widely assumed that each of these fusion processes is driven by a specific protein fusogen, it is tempting to hypothesize that some of these relatively slow fusions between PS-exposing cells involve ubiquitous extracellular Anxs.

To summarize, the LPC-block approach developed in this work can be used for identification of proteins required for synchronized myoblast fusion and, thus, at the fusion stage of myogenesis. We dissected myoblast fusion into two distinct stages with an early stage of membrane merger involving extracellular Anx A1 and A5 and subsequent syncytium formation dependent on DNM activity and PtdIns(4,5)P2 content. Interestingly, some mutations in DNM2 and myotubularin, a protein involved in turnover of phosphoinositides, cause centronuclear myopathies characterized by an abnormal localization of cell nuclei and, possibly, are related to a delay in muscle fiber maturation (Spiro et al., 1966; Bitoun et al., 2005; Hnia et al., 2012).

\section{Materials and methods}

\section{Reagents}

$\mathrm{rA} 1$ and $\mathrm{A} 5$ were either purchased from US Biological or BD, respectively, or expressed in Escherichia coli (BL21DE3) and purified in-house. Anx A1 plasmid DNA (Blume et al., 2009) was a gift from K. Lauber (University of Tübingen, Tübingen, Germany) and Anx A5 plasmid (plasmid pET12aPAPI) was purchased from Addgene. The cells grown in LB medium in the presence of $100 \mathrm{mg} / \mathrm{ml}$ ampicillin and induced with $1 \mathrm{mM} \mathrm{IPTG}$ for protein expression were lysed by sonication. In the case of $A n x A 1$ we followed the protocol described in Logue et al. (2009). The soluble fraction of the cell extract was incubated overnight with Ni-NTA agarose (QIAGEN). After three washes with buffer containing $25 \mathrm{mM}$ imidazole, 6-His-tagged Anx Al was eluted with the buffer containing $100 \mathrm{mM}$ imidazole. The eluted protein was dialyzed overnight in PBS, $\mathrm{pH} 7.4$, without imidazole and then treated with biotinylated thrombin to cleave the $\mathrm{N}$-terminal His tag; the thrombin was removed by incubating the protein with streptavidin agarose. In the case of Anx A5, we followed Elegbede et al. (2006). The overexpressed protein was purified from the inclusion bodies. The sonication was performed in the presence of $5 \mathrm{mM} \mathrm{Ca}^{2+}$. Anx A5 binds to anionic lipids of the broken cell membranes and ends up in the insoluble fraction of the cell lysate. The cell pellet containing Anx A5 was dissolved in a buffer containing $6 \mathrm{M}$ urea and $6 \mathrm{mM}$ EDTA and left to stir overnight 
at room temperature. The suspension was centrifuged and the soluble fraction was diluted 10 -fold as in a snap-dilution method in the refolding buffer containing $5 \mathrm{mM} \mathrm{Ca}^{2+}$. This solution was left to stir overnight at $4^{\circ} \mathrm{C}$, producing a cloudy suspension of the protein. The resulting cloudy suspension was centrifuged and the pellet was resuspended in the extraction buffer containing $10 \mathrm{mM}$ EDTA and $10 \mathrm{mM}$ EGTA. The pellet was stirred for $4 \mathrm{~h}$ at room temperature and then centrifuged. The supernatant containing Anx A5 was extensively dialyzed. Purified Anxs were aliquoted and stored at $-80^{\circ} \mathrm{C}$.

Synthetic peptide mimicking $\mathrm{N}$-terminal regions of human $\mathrm{Anx}$ Al (2-26; Ac-AMVSEFLKQAWFIENEEQEYVQTVK), peptide with the same amino acid composition but a scrambled sequence (Ac-EMQSNAAVQYVEIKTWLEFEVKEQF), and peptide mimicking the N-terminal region of human Anx A5 (2-20; Ac-AQVLRGTVTDFPGFDERAD) and its scrambled version (Ac-LVATGGAVRPEDTFDRQDF) were custom synthesized by AnaSpec. Neither the A1-nor the A5-peptide affected fusion of those myoblasts that did not express the corresponding Anx (Fig. S5 B). The siRNA against murine $A n x A 1$ and $A 5, D N M 2$, and control siRNA, a scrambled sequence not causing the specific degradation of any cellular message, were purchased from Santa Cruz Biotechnology, Inc. Rabbit polyclonal antibodies to Anx A land A5 used in functional and immunofluorescence experiments were purchased from Abcam. We used primary myoblasts from Anx Al- (Hannon et al., 2003) and Anx A5-deficient (Brachvogel et al., 2003) mice to verify that these antibodies to Anx Al and $\mathrm{A} 5$ have no cross-reactivity in immunofluorescence and in Western blots. Non-specific rabbit polyclonal lgG and antibodies to $\beta$-tubulin were purchased from Abcam. The rabbit polyclonal anti-Anx Al antibody used in Western blots was purchased from Santa Cruz Biotechnology, Inc.

The fluorescent lipophilic tracers Vybrant Dil and membrane-permeant green CMFDA and orange CMRA cell trackers were purchased from Molecular Probes. LPC (1-lauroyl-2-hydroxy-sn-glycero-3-phosphocholine) was purchased from Avanti Polar Lipids, Inc. 1-butanol, 2-butanol, t-butanol, sodium azide, 2-D-deoxyglucose, and DNM GTPase inhibitors dynasore (Macia et al., 2006) and MiTMAB (Quan et al., 2007) were purchased from Sigma-Aldrich. The polyphosphoinositide binding peptide PBP10, a rhodamine B-tagged 10-residue peptide derived from the Ptdlns $(4,5)$ P2 binding region in segment 2 of gelsolin (Cunningham et al., 2001), was purchased from EMD Millipore.

\section{Animals}

National Institutes of Health and Public Health Service policy was followed for all animal research, which was approved by the Eunice Kennedy Shriver National Institute of Child Health and Human Development Animal Care and Use Committee. Anx Al knockout animals (Hannon et al., 2003) were purchased from Charles River. These animals carry an insertion/deletion mutation that interrupts exon 2 and deletes exons 3 and 4 of Anx Al. Anx A5 knockout animals (Brachvogel et al., 2003) were a gift of E. Pöschl (University of East Anglia, Norwich, UK) and B. Brachvogel (University of Cologne, Cologne, Germany) and carry an insertion/deletion mutation that interrupts exon 3 and deletes exon 4 of Anx A5. Both mouse strains are in a C57BL/6 background. WT C57BL/6 mice were obtained from National Cancer Institute, Frederick. To generate offspring for the in vitro culture of primary mouse myoblasts, matings were set up for each genotype. To confirm the homozygous deletion of the Anx Al and A5 genes in the offspring of $A n \times \mathrm{Al}^{-1-}$ mice and $A n \times \mathrm{A}^{-1-}$ mice, we performed toe clipping at P4 and extracted genomic DNA using Direct PCR (Tail) solution (Viagen Biotech) and Proteinase $\mathrm{K}$ (Roche). Anx $\mathrm{Al}^{-/-}$genotyping was performed by individual PCRs for the WT and $A n \times A 1^{-/-}$genotypes. We used primers 5'-GCCTTGCACAAAGCTATCATGG-3' and 5'-GCATTGGTCCTCTTGGTAAGAATG-3' to generate a 700-bp product specific to the WT allele and primers 5'-TACTGTCGTCGTCCCCTCAAACTG-3' and 5'-GTTGCACCACAGATGAAACGC-3' to detect a 220-bp amplicon specific to the mutant allele (Hannon et al., 2003). Standard PCR reactions and conditions were also used to genotype the $A n x$ A5 deletion using the following primer pairs (suggested by E. Pöschl): WT, 5'-TGGGGAGAGACTTGCCAAC-3' (Anxa5-Int2) and 5'-AATTAAACGTTACCCAAGCC-3' (Anxa5-Int/Ex3.rev); knockout, 5'-TGGGGAGAGACTTGCCAAC-3' (Anxa5-Int2) and 5'-TGCGGGCCTCTTCGCTATTACG-3' (Anxa5-LacZ. rev). Pups were killed at postnatal day 6 to dissect neonatal muscle tissue.

\section{Cells}

We isolated primary myoblasts from the forelimbs and hindlimbs of three to four 5-d-old pups of the same littermate as described previously (Bois and Grosveld, 2003). The dissected/minced muscle was enzymatically disaggregated in $6 \mathrm{ml}$ PBS including $1.5 \mathrm{U} / \mathrm{ml}$ dispase $1 /$ and $1.4 \mathrm{U} / \mathrm{ml}$ collagenase $\mathrm{D}$ (Roche) and triturated with a $10-\mathrm{ml}$ pipette every $5 \mathrm{~min}$ for $20 \mathrm{~min}$ at $37^{\circ} \mathrm{C}$.

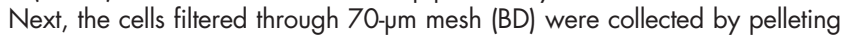

at 1,000 rpm for $5 \mathrm{~min}$, and cell pellet was dissociated in $10 \mathrm{ml}$ of $\mathrm{F} 10 \mathrm{me}-$ dium (Invitrogen) supplemented with $10 \mathrm{ng} / \mathrm{ml}$ of basic fibroblast growth factor (PeproTech) and 10\% cosmic calf serum (Hyclone; referred to as growth medium 1 [GM1]). Finally, the cells were preplated onto a normal tissue culture dish twice for $1 \mathrm{~h}$ to deplete the population of fibroblasts, which generally adhere faster than myoblasts. The preplating was repeated during the following four passages. Starting from the fifth passage, the cells were used in the experiments. The minimal myogenic purity of our primary myoblast cultures as assessed by immunofluorescence using rabbit antibodies to the muscle cell marker desmin (Abcam) exceeded 95\%. We compared time courses of myotube formation and the extents of inhibition of myotube formation by $\mathrm{Al}$ and A5 siRNAs for multiple (three to five) independently isolated WT cultures and found no major differences between different isolates. Based on these results, each of the primary myoblast cultures used in the experiments (WT, Anx $\mathrm{Al}^{-/-}$, and $\mathrm{Anx}{\mathrm{A} 5^{-1-}}^{-}$represented a single independent isolate originated by pooling together cells from three to four pups.

Mouse-derived C2C12 myoblasts (Blau et al., 1983; American Type Culture Collection) were cultured in DMEM (Invitrogen) containing $2 \mathrm{mM}$ L-glutamine supplemented with antibiotics $(10,000 \mathrm{U} / \mathrm{ml}$ penicillin and $10 \mathrm{mg} / \mathrm{ml}$ streptomycin) and $10 \%$ heat-inactivated fetal calf serum, referred to as growth medium 2 (GM2).

To induce differentiation, primary myoblasts and $\mathrm{C} 2 \mathrm{C} 12$ cells at $75 \%$ confluency were placed into DMEM containing antibiotics and 5\% horse serum (Invitrogen), referred to as DM.

\section{Cell preparation}

We labeled cells with Dil, green, and orange cell tracker, as recommended by the manufacturer. $\mathrm{C} 2 \mathrm{C} 12$ cells were labeled $48 \mathrm{~h}$ after placement in DM. Differently labeled cells were allowed to attach for 2-3 h after coplating before application of LPC or other reagents. Fusion was scored $16 \mathrm{~h}$ later, i.e., $\sim 67 \mathrm{~h}$ after triggering of myogenic differentiation.

In the experiments on the time course of myogenesis for primary myoblasts, we labeled proliferating cells in GMI, lifted them with versene, and coplated differently labeled cells in DM to start the myogenesis $(t=0)$. To synchronize fusion of primary myoblasts, $7 \mathrm{~h}$ later we placed the cells into LPC-supplemented DM for $16 \mathrm{~h}$, and then applied LPC-free DM supplemented or not with different reagents.

\section{LPC block}

A $10-\mathrm{mg} / \mathrm{ml}$ stock solution of LPC was freshly prepared in water. To reversibly block fusion and accumulate ready-to-fuse myoblasts, we incubated the cells in DM supplemented with $300 \mu$ M LPC. Fusion ensued when LPC was removed in three washes with LPC-free DM. The membrane-inserted LPC that mediates fusion inhibition is rapidly internalized and metabolized, and because we needed to keep the fusion blocked for $16 \mathrm{~h}$, we used lauroyl LPC to maintain a continuous supply of our lipid inhibitor in the medium. Importantly, the relatively high solubility of lauroyl LPC in water also facilitated its removal and thus the removal of the fusion block by washing the cells with LPC-free medium.

\section{Application of reagents}

In the experiments on synchronized fusion, different reagents were added to the LPC-free medium in which the cells were kept after LPC withdrawal. In the experiments in which we did not block the fusion stage with LPC, the reagents were applied 16 or $3 \mathrm{~h}$ before scoring fusion for $\mathrm{C} 2 \mathrm{C} 12$ cells and primary myoblasts, respectively. We used antibodies to $A n x A 1$ at $2.5 \mu \mathrm{g} / \mathrm{ml}$; antibodies to Anx A5 or control lgG both at $10 \mu \mathrm{g} / \mathrm{ml}$; Al- and A5peptides and their scrambled versions at $100 \mathrm{\mu g} / \mathrm{ml}$; and $\mathrm{rAl}$ and $\mathrm{rA} 5$ at $50 \mu \mathrm{g} / \mathrm{ml}$. Inhibitor of DNM GTPase dynasore was used at $80 \mu \mathrm{M}$ for C2C 12 cells and 50 or $100 \mu \mathrm{M}$ for primary myoblasts. Another DNM inhibitor, MiT$M A B$, was used at $25 \mu \mathrm{M}$ for $\mathrm{C} 2 \mathrm{C} 12$ cells and 2.5 or $10 \mu \mathrm{M}$ for primary myoblasts. In the experiments with reagents lowering the concentration of plasma membrane Ptdlns(4,5)P2 accessible for interactions with intracellular proteins, we used 5 or $7.5 \mu \mathrm{M} \mathrm{PBP10}$ and $1 \% 1$-butanol or its inactive isomers 2-butanol and t-butanol. To explore the effects of intracellular ATP depletion on the synchronized fusion stage, we applied a mix of $10 \mathrm{mM}$ sodium azide and $20 \mathrm{mM}$ 2-D-deoxyglucose in DM or in PBS to fusion-committed primary myoblasts or $\mathrm{C} 2 \mathrm{C} 12$ cells, respectively, in the presence of LPC $5 \mathrm{~min}$ before LPC removal. EGTA was applied to $\mathrm{C} 2 \mathrm{C} 12$ cells $30 \mathrm{~min}$ before LPC removal as $\mathrm{Ca}^{2+}$ - and $\mathrm{Mg}^{2+}$-free $\mathrm{LPC}$-containing PBS supplemented with $10 \mathrm{mM}$ EGTA. At the time of LPC removal, we replaced this buffer with $\mathrm{Ca}^{2+}$. and $\mathrm{Mg}^{2+}$-free LPC-containing PBS supplemented with 10 mM EGTA.

\section{Cell fusion assays}

To quantify the efficiency of myoblast fusion, we fixed the cells in phosphate buffered 10\% wt/vol formalin solution (Electron Microscopy Sciences). 
Cell nuclei were labeled with Hoechst-33342 (Molecular Probes). Images were taken at room temperature in PBS on Axioskop microscope (Carl Zeiss) equipped with $20 \times / 0.3$ LD A-Plan objective lens (Carl Zeiss) and ORCA C4742-98 charge-coupled device camera (Hamamatsu Photonics) using MetaMorph 6.1 software (Molecular Devices). We prepared and analyzed images using ImageJ (National Institutes of Health). For each condition we took images of 10 randomly chosen fields of view (the total numbers of nuclei per condition averaged $\sim 800-1,000$ for $\mathrm{C} 2 \mathrm{C} 12$ cells and 1,000-1,800 for primary myoblasts). The efficiency of myotube formation was quantified as the percentage of cell nuclei present in myotubes normalized to the total number of cell nuclei. We also assayed fusion as the redistribution of $\mathrm{Dil}$ and green cell tracker between differently labeled cells and presented it as the percentage of nuclei in colabeled cells (including both mono- and multinucleated cells) compared with the number of contacts of differently labeled cells. The percentage of nuclei in multinucleated cells (syncytium formation assay) and the percentage of nuclei in colabeled cells (lipid mixing assay) after different treatments were normalized to those in the parallel control experiments $(20-50 \%$ for both $\mathrm{C} 2 \mathrm{C} 12$ cells and WT primary myoblasts).

In the experiments with the primary myoblasts that were cotransfected with GFP vector and siRNAs, we separately evaluated the efficiency of cell fusion (myotube formation) for transfected cells and, within the same plate, cells that were not transfected. For each field of view, we separately scored fusion for GFP-labeled (transfected) and unlabeled (nontransfected) cells. For each condition, the percentage $\mathrm{P}$ of cell nuclei in the mononucleated cells compared with the total number of cell nuclei in the field of view was used to estimate the efficiency of myotube formation as (100-P)\%.

In each experiment on synchronized fusion, we had controls in which we measured fusion extents 30 min after application of LPC (if not stated otherwise) and fusion extents observed if LPC was not washed out $\left(F_{\text {LPCon }}\right)$. We also measured fusion extents for the cells that were released from LPC block without being treated with the reagents studied $\left(F_{c}\right)$. $F_{L P C o n}$ and $F_{c}$ varied from day to day in the $6-10 \%$ and $20-40 \%$ range, respectively. To normalize the data for each condition, we subtracted $F_{L P C o n}$ from the measured fusion extents, divided the result by $\left(\mathrm{F}_{\mathrm{c}}-\mathrm{F}_{\mathrm{LPCon}}\right)$, and multiplied by 100 to present as a percentage.

\section{Time-lapse recordings}

Time-lapse images were recorded every 2 min using an iXon 885 EMCCD camera (Andor Technology) and Micro-Manager software package (Edelstein et al., 2010) on an AxiObserver D1 inverted microscope (Carl Zeiss) equipped with a $10 \times / 0.45 \mathrm{Ph} 1$ Plan-Apochromat objective lens (Carl Zeiss) and 617-nm LED transmitted light source (Mightex Systems). Temperature was maintained at $37^{\circ} \mathrm{C}$ using DH-35iL culture dish incubator (Warner Instruments) under constant stream of $95 \%$ air $/ 5 \% \mathrm{CO}_{2}$ gas mixture. Image sequences were converted into uncompressed avi files using ImageJ 1.47d (National Institutes of Health) and then compressed into mp4 files using Handbrake 0.9.8 open source software.

\section{Immunofluorescence assay for cell surface-bound Anx 1 and Anx 5}

The cells were incubated with primary antibodies in DM for $2 \mathrm{~h}$ at $4^{\circ} \mathrm{C}$, washed four times with cold PBS supplemented with $5 \%$ FBS, and then fixed for $10 \mathrm{~min}$ at $37^{\circ} \mathrm{C}$ in $4 \%$ formaldehyde in phosphate buffer with $5 \%$ FBS. After four washes with PBS supplemented with $5 \% \mathrm{FBS}$, the cells were incubated with secondary antibodies (Alexa Fluor 488 goat anti-rabbit IgG; Invitrogen; 1:300 dilution) for an hour followed by four washes with PBS. Fixed cells were imaged using an inverted fluorescence microscope (Eclipse Ti; Nikon) equipped with a $60 x, 1.49$ NA objective (Nikon), TIRFillumination arm, custom-built laser combiner $(405,488,561$, and $640 \mathrm{~nm}$; Coherent), and Ixon 885 EMCCD camera. Microscope, lasers, and camera were controlled using Micro-Manager 1.4.10. The incident angle of the laser beam was set by a motorized TIRF unit to wide-field illumination $\left(90^{\circ}\right)$. Fluorescence and transmitted light channels were collected using alternating 488-nm laser and transmitted light sources through a quad-band dichroic and emission filter set (405/488/561/640; Semrock). 30 frames were acquired for each field of view and averaged together to increase signal to noise ratio. Images were manually thresholded to separate cells from cell-free regions (the same threshold was used for all experimental conditions). The median fluorescence signal from the cells was corrected for background by subtraction of the median fluorescence signal from cellfree regions. These values were further corrected for nonspecific antibody binding by subtraction of the background corrected signal measured in a sample incubated with labeled secondary antibodies but not with Anxspecific primary antibodies. Finally, these values were normalized to a signal observed for cells not induced to myoblast differentiation.
Immunofluorescence assay for myogenin and MHC

To analyze the levels of expression of myogenin and $M H C$, the cells were fixed for $10 \mathrm{~min}$ at $37^{\circ} \mathrm{C}$ in $4 \%$ formaldehyde in phosphate buffer with $5 \%$ FBS and, after four washes with PBS with 5\% FBS, permeabilized in $0.1 \%$ Triton/PBS solution for $3 \mathrm{~min}$ at room temperature. Cells were incubated with primary antibodies $(1: 1,000)$ for an hour at room temperature, washed four times with PBS, and then incubated with secondary antibodies (Alexa Fluor 488 goat anti-rabbit lgG; Invitrogen; 1:1,000 dilution) for an hour and finally washed four times with PBS. Images were recorded either on a confocal microscope (LSM 510; Carl Zeiss) using manufacturersupplied software package or using Micro-Manager software package on AxiObserver.D1 (Carl Zeiss) inverted microscope equipped with iXon 885 EMCCD camera and pE-2 LED light source (CoolLed). In both cases PlanApochromat 20x/0.8 (Carl Zeiss) objective lens was used. Images were analyzed in ImageJ. To create frequency distribution of myogenin expression level within cell nuclei, we used Hoechst staining to automatically create a region of interest for each cell nucleus and measure average pixel intensity for anti-myogenin staining within these regions. Anti-myogenin signal was corrected for background using ImageJ built-in rolling-ball algorithm with the radius parameter equal twice the diameter of the largest cell nucleus. Because cytosolic distribution of MHC made automated analysis of images significantly more difficult, we do not present cell distribution analysis for MHC labeling.

\section{Western blotting}

To immunoblot Anxs, the culture plates were incubated on ice for $15 \mathrm{~min}$. Then the cells were washed with ice-cold PBS. The cells were lysed with RIPA buffer containing protease inhibitor cocktail (Sigma-Aldrich). The lysate was transferred into an Eppendorf tube, vortexed for $60 \mathrm{~s}$, and centrifuged for $10 \mathrm{~min}$ at $15,000 \mathrm{rpm}$. The soluble fraction of the lysate was added to the denaturing sample buffer (Invitrogen), boiled, loaded onto a 4-12\% NuPAGE Bis-Tris gel (Invitrogen) or 3-8\% NuPAGE Tris-acetate gel (Invitrogen), and separated with SDS-PAGE. The separated proteins were transferred electrophoretically to a PVDF membrane (Invitrogen). After the transfer, the membrane was blocked with $5 \%$ nonfat dry milk dissolved in PBS containing $0.05 \%$ Tween 20 (Sigma-Aldrich). The membrane was incubated at room temperature for $1 \mathrm{~h}$ with the rabbit polyclonal anti-Anx $\mathrm{A} 1$ and rabbit polyclonal anti-Anx A5 antibodies. After incubation, the membrane was washed three times with PBS containing 0.05\% Tween 20, and then incubated with alkaline phosphatase-conjugated goat anti-rabbit lgG (Thermo Fisher Scientific). The membrane was washed three times again with PBS containing $0.05 \%$ Tween 20 , and the protein bands were visualized with enhanced chemifluorescence (ECF reagent; GE Healthcare). To immunoblot DNM2, we lysed the cells for $1 \mathrm{~h}$ at room temperature with 0.1 Triton X-100 and $0.2 \%$ SDS in phosphate buffer in the presence of protease inhibitors and used 3-8\% NuPAGE Tris-acetate gel.

\section{siRNA transfection}

Proliferating cells coplated in $35 \times 10$ collagen-covered dishes (BD) in GM1 (primary myoblasts) or GM2 (C2C12 cells) at $80 \%$ confluency were transfected with siRNAs (100 pM/plate) with or without GFP vector $(0.5 \mathrm{\mu g} /$ plate) or with GFP vector only using Lipofectamine 2000 (Invitrogen), as recommended by the manufacturer. The cells were placed into DM $16 \mathrm{~h}$ later. Fusion was scored 24 or $36 \mathrm{~h}$ later for primary and $\mathrm{C} 2 \mathrm{C} 12$ cells, respectively. In some experiments, we then lysed the cells and analyzed the lysates using quantitative Western blotting. We verified that $A 1$ siRNA had no significant effect on expression of Anx A5, and vice versa. In the experiments with DNM2 siRNA, we incubated primary myoblasts for $16 \mathrm{~h}$ in DM, labeled them, and then transfected coplated cells and let the cells continue differentiation in DM. Fusion was scored $24 \mathrm{~h}$ later.

\section{Analysis and presentation of experimental data}

We prepared graphs and performed statistical analyses using Sigmaplot v.11.0 (Systat Software). We compared normally distributed data using the unpaired Student's $t$ test, and when the data were not normally distributed or failed the equal variance test, we used the Mann-Whitney rank sum test instead. Data are presented as the means \pm SEM with the number of experiments stated.

\section{Online supplemental material}

Fig. S1 shows that neither deficiency of Anx Al or A5 in primary myoblasts nor 16-h incubation of WT myoblasts in the presence of LPC blocks myogenic differentiation assayed as expression of myogeninin and $M H C$. Fig. S2 shows promotion of myoblast fusion by $\mathrm{rA} 1$ and $\mathrm{rA} 5$. Fig. S3 shows elevation of the amounts of Anx Al and A5 at the outer surface of 
$\mathrm{C} 2 \mathrm{C} 12$ cells at the time of myotube formation. Fig. S4 shows that DNM inhibitors block myotube formation by $\mathrm{C} 2 \mathrm{C} 12$ cells at a stage that follows lipid mixing but precedes formation of fusion pores large enough to pass the cell tracker-labeled proteins. Fig. S5 shows the specificity of the effects of A1- and A5- peptides and Anx siRNA on myoblast fusion. Video 1 shows a much higher rate of fusion events for myoblasts released from LPC block than the rates normally observed in myogenesis (Video 2). Online supplemental material is available at http://www.jcb .org/cgi/content/full/jcb.201207012/DC1.

The Anx A5 knockout mice were provided by Drs. Ernst Pöschl and Bent Brachvogel, and Anx Al plasmid DNA was a gift from Dr. Kirsten Lauber. The authors thank Drs. Alexander Grinberg and Joshua Zimmerberg for helpful discussions.

This research was supported by the Intramural Research Program of the Eunice Kennedy Shriver National Institute of Child Health and Human Development, National Institutes of Health.

Submitted: 2 July 2012

Accepted: 5 December 2012

\section{References}

Abmayr, S.M., and G.K. Pavlath. 2012. Myoblast fusion: lessons from flies and mice. Development. 139:641-656. http://dx.doi.org/10.1242/dev.068353

Arcuri, C., I. Giambanco, R. Bianchi, and R. Donato. 2002. Annexin V, annexin VI, S100A1 and S100B in developing and adult avian skeletal muscles. Neuroscience. 109:371-388. http://dx.doi.org/10.1016/ S0306-4522(01)00330-X

Bach, A.S., S. Enjalbert, F. Comunale, S. Bodin, N. Vitale, S. Charrasse, and C. Gauthier-Rouvière. 2010. ADP-ribosylation factor 6 regulates mammalian myoblast fusion through phospholipase D1 and phosphatidylinositol 4,5-bisphosphate signaling pathways. Mol. Biol. Cell. 21:2412-2424. http://dx.doi.org/10.1091/mbc.E09-12-1063

Belluoccio, D., I. Grskovic, A. Niehoff, U. Schlötzer-Schrehardt, S. Rosenbaum, J. Etich, C. Frie, F. Pausch, S.E. Moss, E. Pöschl, et al. 2010. Deficiency of annexins A5 and A6 induces complex changes in the transcriptome of growth plate cartilage but does not inhibit the induction of mineralization. J. Bone Miner. Res. 25:141-153. http://dx.doi.org/10.1359/jbmr.090710

Bitoun, M., S. Maugenre, P.Y. Jeannet, E. Lacène, X. Ferrer, P. Laforêt, J.J. Martin, J. Laporte, H. Lochmüller, A.H. Beggs, et al. 2005. Mutations in dynamin 2 cause dominant centronuclear myopathy. Nat. Genet. 37:1207-1209. http://dx.doi.org/10.1038/ng1657

Bitto, E., and W. Cho. 1999. Structural determinant of the vesicle aggregation activity of annexin I. Biochemistry. 38:14094-14100. http://dx.doi org/10.1021/bi990457p

Bizzarro, V., B. Fontanella, S. Franceschelli, M. Pirozzi, H. Christian, L. Parente, and A. Petrella. 2010. Role of Annexin A1 in mouse myoblast cell differentiation. J. Cell. Physiol. 224:757-765. http://dx.doi .org/10.1002/jcp. 22178

Blau, H.M., C.P. Chiu, and C. Webster. 1983. Cytoplasmic activation of human nuclear genes in stable heterocaryons. Cell. 32:1171-1180. http://dx.doi org/10.1016/0092-8674(83)90300-8

Blume, K.E., S. Soeroes, M. Waibel, H. Keppeler, S. Wesselborg, M. Herrmann, K. Schulze-Osthoff, and K. Lauber. 2009. Cell surface externalization of annexin $\mathrm{A} 1$ as a failsafe mechanism preventing inflammatory responses during secondary necrosis. J. Immunol. 183:8138-8147. http://dx.doi .org/10.4049/jimmunol.0902250

Bois, P.R., and G.C. Grosveld. 2003. FKHR (FOXO1a) is required for myotube fusion of primary mouse myoblasts. EMBO J. 22:1147-1157. http:// dx.doi.org/10.1093/emboj/cdg116

Boucrot, E., S. Saffarian, R. Massol, T. Kirchhausen, and M. Ehrlich. 2006. Role of lipids and actin in the formation of clathrin-coated pits. Exp. Cell Res. 312:4036-4048. http://dx.doi.org/10.1016/j.yexcr.2006.09.025

Bouter, A., C. Gounou, R. Bérat, S. Tan, B. Gallois, T. Granier, B.L. d'Estaintot, E. Pöschl, B. Brachvogel, and A.R. Brisson. 2011. Annexin-A5 assembled into two-dimensional arrays promotes cell membrane repair. Nat. Commun. 2:270. http://dx.doi.org/10.1038/ncomms 1270

Brachvogel, B., J. Dikschas, H. Moch, H. Welzel, K. von der Mark, C. Hofmann, and E. Pöschl. 2003. Annexin A5 is not essential for skeletal development. Mol. Cell. Biol. 23:2907-2913. http://dx.doi.org/ 10.1128/MCB.23.8.2907-2913.2003

Casadei, L., L. Vallorani, A.M. Gioacchini, M. Guescini, S. Burattini, A. D'Emilio, L. Biagiotti, E. Falcieri, and V. Stocchi. 2009. Proteomicsbased investigation in $\mathrm{C} 2 \mathrm{C} 12$ myoblast differentiation. Eur. J. Histochem. $53: 261-268$
Chen, E.H., E. Grote, W. Mohler, and A. Vignery. 2007. Cell-cell fusion. FEBS Lett. 581:2181-2193. http://dx.doi.org/10.1016/j.febslet.2007.03.033

Chernomordik, L.V., and M.M. Kozlov. 2005. Membrane hemifusion: crossing a chasm in two leaps. Cell. 123:375-382. http://dx.doi.org/10.1016/ j.cell.2005.10.015

Clemen, C.S., A. Hofmann, C. Zamparelli, and A.A. Noegel. 1999. Expression and localisation of annexin VII (synexin) isoforms in differentiating myoblasts. J. Muscle Res. Cell Motil. 20:669-679. http://dx.doi.org/ 10.1023/A:1005524623337

Cunningham, C.C., R. Vegners, R. Bucki, M. Funaki, N. Korde, J.H. Hartwig, T.P. Stossel, and P.A. Janmey. 2001. Cell permeant polyphosphoinositidebinding peptides that block cell motility and actin assembly. J. Biol. Chem. 276:43390-43399. http://dx.doi.org/10.1074/jbc.M105289200

Doherty, K.R., A. Cave, D.B. Davis, A.J. Delmonte, A. Posey, J.U. Earley, M. Hadhazy, and E.M. McNally. 2005. Normal myoblast fusion requires myoferlin. Development. 132:5565-5575. http://dx.doi.org/10.1242/ dev.02155

Doherty, J.T., K.C. Lenhart, M.V. Cameron, C.P. Mack, F.L. Conlon, and J.M. Taylor. 2011. Skeletal muscle differentiation and fusion are regulated by the BAR-containing Rho-GTPase-activating protein (Rho-GAP), GRAF1. J. Biol. Chem. 286:25903-25921. http://dx.doi.org/10.1074/jbc .M111.243030

Draeger, A., K. Monastyrskaya, and E.B. Babiychuk. 2011. Plasma membrane repair and cellular damage control: the annexin survival kit. Biochem. Pharmacol. 81:703-712. http://dx.doi.org/10.1016/j.bcp.2010.12.027

Duan, R. 2008. Molecular mechanisms governing skeletal muscle myoblast fusion. $\mathrm{PhD}$ thesis. Indiana University, Bloomington, IN. $114 \mathrm{pp}$.

Edelstein, A., N. Amodaj, K. Hoover, R. Vale, and N. Stuurman. 2010. Computer control of microscopes using microManager. Curr. Protoc. Mol. Biol. Chapter 14:Unit14.20.

Elegbede, A.I., D.K. Srivastava, and A. Hinderliter. 2006. Purification of recombinant annexins without the use of phospholipids. Protein Expr. Purif. 50:157-162. http://dx.doi.org/10.1016/j.pep.2006.05.003

Fan, X., S. Krahling, D. Smith, P. Williamson, and R.A. Schlegel. 2004 Macrophage surface expression of annexins I and II in the phagocytosis of apoptotic lymphocytes. Mol. Biol. Cell. 15:2863-2872. http://dx.doi .org/10.1091/mbc.E03-09-0670

Francis, J.W., K.J. Balazovich, J.E. Smolen, D.I. Margolis, and L.A. Boxer. 1992. Human neutrophil annexin I promotes granule aggregation and modulates $\mathrm{Ca}(2+)$-dependent membrane fusion. J. Clin. Invest. 90:537544. http://dx.doi.org/10.1172/JCI115892

Gauster, M., and B. Huppertz. 2008. Fusion of cytothrophoblast with syncytiotrophoblast in the human placenta: factors involved in syncytialization. Journal für Reproduktionsmedizin und Endokrinologie. 5:76-82.

Gerke, V., and S.E. Moss. 2002. Annexins: from structure to function. Physiol. Rev. 82:331-371.

Gerke, V., C.E. Creutz, and S.E. Moss. 2005. Annexins: linking Ca2+ signalling to membrane dynamics. Nat. Rev. Mol. Cell Biol. 6:449-461. http:// dx.doi.org/10.1038/nrm1661

Gonnet, F., B. Bouazza, G.A. Millot, S. Ziaei, L. Garcia, G.S. Butler-Browne, V. Mouly, J. Tortajada, O. Danos, and F. Svinartchouk. 2008. Proteome analysis of differentiating human myoblasts by dialysis-assisted twodimensional gel electrophoresis (DAGE). Proteomics. 8:264-278. http:// dx.doi.org/10.1002/pmic.200700261

Gruenbaum-Cohen, Y., I. Harel, K.B. Umansky, E. Tzahor, S.B. Snapper, B.Z. Shilo, and E.D. Schejter. 2012. The actin regulator N-WASp is required for muscle-cell fusion in mice. Proc. Natl. Acad. Sci. USA. 109:1121111216. http://dx.doi.org/10.1073/pnas.1116065109

Hannon, R., J.D. Croxtall, S.J. Getting, F. Roviezzo, S. Yona, M.J. Paul-Clark, F.N. Gavins, M. Perretti, J.F. Morris, J.C. Buckingham, and R.J. Flower. 2003. Aberrant inflammation and resistance to glucocorticoids in annexin 1-/- mouse. FASEB J. 17:253-255.

Hnia, K., I. Vaccari, A. Bolino, and J. Laporte. 2012. Myotubularin phosphoinositide phosphatases: cellular functions and disease pathophysiology. Trends Mol. Med. 18:317-327. http://dx.doi.org/10.1016/ j.molmed.2012.04.004

Hoekstra, D., R. Buist-Arkema, K. Klappe, and C.P. Reutelingsperger. 1993. Interaction of annexins with membranes: the $\mathrm{N}$-terminus as a governing parameter as revealed with a chimeric annexin. Biochemistry. 32:1419414202. http://dx.doi.org/10.1021/bi00214a019

Jeong, J., and I.M. Conboy. 2011. Phosphatidylserine directly and positively regulates fusion of myoblasts into myotubes. Biochem. Biophys. Res. Commun. 414:9-13. http://dx.doi.org/10.1016/j.bbrc.2011.08.128

Jin, C.H., C. Miyaura, H. Tanaka, J. Takito, E. Abe, and T. Suda. 1990. Fusion of mouse alveolar macrophages induced by 1 alpha,25-dihydroxyvitamin D3 involves extracellular, but not intracellular, calcium. J. Cell. Physiol. 142:434-439. http://dx.doi.org/10.1002/jcp.1041420229 
Kaspar, P., and M. Dvorák. 2008. Involvement of phosphatidylserine externalization in the down-regulation of c-myb expression in differentiating C2C12 cells. Differentiation. 76:245-252. http://dx.doi.org/10.1111/ j.1432-0436.2007.00222.x

Kim, S., K. Shilagardi, S. Zhang, S.N. Hong, K.L. Sens, J. Bo, G.A. Gonzalez, and E.H. Chen. 2007. A critical function for the actin cytoskeleton in targeted exocytosis of prefusion vesicles during myoblast fusion. Dev. Cell. 12:571-586. http://dx.doi.org/10.1016/j.devcel.2007.02.019

Kislinger, T., A.O. Gramolini, Y. Pan, K. Rahman, D.H. MacLennan, and A Emili. 2005. Proteome dynamics during $\mathrm{C} 2 \mathrm{C} 12$ myoblast differentiation. Mol. Cell. Proteomics. 4:887-901. http://dx.doi.org/10.1074/mcp .M400182-MCP200

Kubista, H., S. Sacre, and S.E. Moss. 2000. Annexins and membrane fusion. Subcell. Biochem. 34:73-131. http://dx.doi.org/10.1007/0-306-46824-7_3

Logue, S.E., M. Elgendy, and S.J. Martin. 2009. Expression, purification and use of recombinant annexin $\mathrm{V}$ for the detection of apoptotic cells. Nat. Protoc. 4:1383-1395. http://dx.doi.org/10.1038/nprot.2009.143

Macia, E., M. Ehrlich, R. Massol, E. Boucrot, C. Brunner, and T. Kirchhausen. 2006. Dynasore, a cell-permeable inhibitor of dynamin. Dev. Cell. 10:839-850. http://dx.doi.org/10.1016/j.devcel.2006.04.002

Makarov, A.A., L.I. Kovalev, M.A. Kovaleva, I.Iu. Toropygin, and S.S. Shishkin. 2009. A study of protein profile changes in differentiating human myoblasts. [In Russian.] Ontogenez. 40:112-119.

McNeil, A.K., U. Rescher, V. Gerke, and P.L. McNeil. 2006. Requirement for annexin A1 in plasma membrane repair. J. Biol. Chem. 281:35202-35207. http://dx.doi.org/10.1074/jbc.M606406200

Moss, S.E., and R.O. Morgan. 2004. The annexins. Genome Biol. 5:219. http:// dx.doi.org/10.1186/gb-2004-5-4-219

Mukai, A., T. Kurisaki, S.B. Sato, T. Kobayashi, G. Kondoh, and N. Hashimoto. 2009. Dynamic clustering and dispersion of lipid rafts contribute to fusion competence of myogenic cells. Exp. Cell Res. 315:3052-3063. http://dx.doi.org/10.1016/j.yexcr.2009.07.010

Nowak, S.J., P.C. Nahirney, A.K. Hadjantonakis, and M.K. Baylies. 2009. Nap1mediated actin remodeling is essential for mammalian myoblast fusion. J. Cell Sci. 122:3282-3293. http://dx.doi.org/10.1242/jcs.047597

Onel, S.F., and R. Renkawitz-Pohl. 2009. FuRMAS: triggering myoblast fusion in Drosophila. Dev. Dyn. 238:1513-1525. http://dx.doi.org/10.1002/ dvdy. 21961

Quan, A., A.B. McGeachie, D.J. Keating, E.M. van Dam, J. Rusak, N. Chau, C.S. Malladi, C. Chen, A. McCluskey, M.A. Cousin, and P.J. Robinson. 2007. Myristyl trimethyl ammonium bromide and octadecyl trimethyl ammonium bromide are surface-active small molecule dynamin inhibitors that block endocytosis mediated by dynamin I or dynamin II. Mol. Pharmacol. 72:1425-1439. http://dx.doi.org/10.1124/mol.107 .034207

Rao, L.V., J.F. Tait, and A.D. Hoang. 1992. Binding of annexin V to a human ovarian carcinoma cell line (OC-2008). Contrasting effects on cell surface factor VIIa/tissue factor activity and prothrombinase activity. Thromb. Res. 67:517-531. http://dx.doi.org/10.1016/0049-3848(92)90013-Z

Reporter, M., and D. Raveed. 1973. Plasma membranes: isolation from naturally fused and lysolecithin-treated muscle cells. Science. 181:863-865. http:// dx.doi.org/10.1126/science.181.4102.863

Richard, J.P., E. Leikina, R. Langen, W.M. Henne, M. Popova, T. Balla, H.T. McMahon, M.M. Kozlov, and L.V. Chernomordik. 2011. Intracellular curvature-generating proteins in cell-to-cell fusion. Biochem. J. 440:185193. http://dx.doi.org/10.1042/BJ20111243

Rochlin, K., S. Yu, S. Roy, and M.K. Baylies. 2010. Myoblast fusion: when it takes more to make one. Dev. Biol. 341:66-83. http://dx.doi.org/10.1016/ j.ydbio.2009.10.024

Salsman, J., D. Top, C. Barry, and R. Duncan. 2008. A virus-encoded cellcell fusion machine dependent on surrogate adhesins. PLoS Pathog. 4:e1000016. http://dx.doi.org/10.1371/journal.ppat.1000016

Sapir, A., O. Avinoam, B. Podbilewicz, and L.V. Chernomordik. 2008. Viral and developmental cell fusion mechanisms: conservation and divergence. Dev. Cell. 14:11-21. http://dx.doi.org/10.1016/j.devcel.2007 .12 .008

Schwoebel, E.D., T.H. Ho, and M.S. Moore. 2002. The mechanism of inhibition of Ran-dependent nuclear transport by cellular ATP depletion. J. Cell Biol. 157:963-974. http://dx.doi.org/10.1083/jcb.200111077

Sens, K.L., S. Zhang, P. Jin, R. Duan, G. Zhang, F. Luo, L. Parachini, and E.H. Chen. 2010. An invasive podosome-like structure promotes fusion pore formation during myoblast fusion. J. Cell Biol. 191:1013-1027. http:// dx.doi.org/10.1083/jcb.201006006

Sessions, A., and A.F. Horwitz. 1983. Differentiation-related differences in the plasma membrane phospholipid asymmetry of myogenic and fibrogenic cells. Biochim. Biophys. Acta. 728:103-111. http://dx.doi.org/ 10.1016/0005-2736(83)90442-X
Shainberg, A., G. Yagil, and D. Yaffe. 1969. Control of myogenesis in vitro by Ca $2+$ concentration in nutritional medium. Exp. Cell Res. 58:163-167. http://dx.doi.org/10.1016/0014-4827(69)90127-X

Spiro, A.J., G.M. Shy, and N.K. Gonatas. 1966. Myotubular myopathy. Persistence of fetal muscle in an adolescent boy. Arch. Neurol. 14:1-14. http://dx.doi.org/10.1001/archneur.1966.00470070005001

Tannu, N.S., V.K. Rao, R.M. Chaudhary, F. Giorgianni, A.E. Saeed, Y. Gao, and R. Raghow. 2004. Comparative proteomes of the proliferating $\mathrm{C}(2) \mathrm{C}(12)$ myoblasts and fully differentiated myotubes reveal the complexity of the skeletal muscle differentiation program. Mol. Cell. Proteomics. 3:10651082. http://dx.doi.org/10.1074/mcp.M400020-MCP200

van den Eijnde, S.M., M.J. van den Hoff, C.P. Reutelingsperger, W.L. van Heerde, M.E. Henfling, C. Vermeij-Keers, B. Schutte, M. Borgers, and F.C. Ramaekers. 2001. Transient expression of phosphatidylserine at cell-cell contact areas is required for myotube formation. J. Cell Sci. $114: 3631-3642$.

van Genderen, H.O., H. Kenis, L. Hofstra, J. Narula, and C.P. Reutelingsperger 2008. Extracellular annexin A5: functions of phosphatidylserine-binding and two-dimensional crystallization. Biochim. Biophys. Acta. 1783:953963. http://dx.doi.org/10.1016/j.bbamcr.2008.01.030

Wakelam, M.J. 1983. Inositol phospholipid metabolism and myoblast fusion. Biochem. J. 214:77-82.

Wakelam, M.J. 1985. The fusion of myoblasts. Biochem. J. 228:1-12.

Wang, L.M., W.H. Li, Y.C. Xu, Q. Wei, H. Zhao, and X.F. Jiang. 2011. Annexin 1-derived peptide Ac2-26 inhibits eosinophil recruitment in vivo via decreasing prostaglandin $\mathrm{D}_{2}$. Int. Arch. Allergy Immunol. 154:137-148. http://dx.doi.org/10.1159/000320228

White, I.J., L.M. Bailey, M.R. Aghakhani, S.E. Moss, and C.E. Futter. 2006 EGF stimulates annexin 1-dependent inward vesiculation in a multivesicular endosome subpopulation. EMBO J. 25:1-12. http://dx.doi.org/ 10.1038/sj.emboj.7600759

Yanagimachi, R. 1978. Calcium requirement for sperm-egg fusion in mammals. Biol. Reprod. 19:949-958. http://dx.doi.org/10.1095/biolreprod19 .5 .949

Yin, C., Q. Long, T. Lei, X. Chen, H. Long, B. Feng, Y. Peng, Y. Wu, and Z. Yang. 2009. Lipid accumulation mediated by adiponectin in $\mathrm{C} 2 \mathrm{C} 12$ myogenesis. BMB Rep. 42:667-672. http://dx.doi.org/10.5483/BMBRep .2009 .42 .10 .667 